\section{W \\ THE W. L. MACKENZIE KING MEMORIAL SCHOLARSHIPS}

Curtis Building, University of British Columbia, 1822 East Mall, Vancouver, BC, V6T 1Z1, Canada

Tel: (1) 6048224564

Fax: (1) 6048228108

Email: mkingscholarships@law.ubc.ca

Website: www.mkingscholarships.ca

Contact: Professor Joost Blom

The Mackenzie King Scholarship Trust consists of two funds established under the will of the Right Honourable William Lyon Mackenzie King (1874-1950). Both scholarships are to support postgraduate study for graduates of Canadian universities.

\section{Mackenzie King Open Scholarship}

Subjects: All subjects.

Eligibility: Open to graduates of any Canadian university. Applicants should be persons of unusual worth or promise as awards are determined on the basis of academic achievement, personal qualities and demonstrated aptitudes. Consideration is also given to the applicant's proposed programme of postgraduate study.

Level of Study: Postgraduate

Type: Scholarship

Value: Canadian $\$ 8,500$ (value is subject to change)

Length of Study: 1 year, non-renewable

Frequency: Annual

Country of Study: Any country

No. of awards offered: 1

Application Procedure: Applicants must complete an application form available from the website. Applications must be submitted to the Dean of Graduate Studies at the Canadian university from which the candidate most recently graduated.

Closing Date: January 15th

Funding: Private

No. of awards given last year: 1

\section{Mackenzie King Travelling Scholarship}

Subjects: International or industrial relations, including international aspects of law, history, politics and economics.

Purpose: To give Canadian students the opportunity to broaden their outlook and sympathies and to contribute in some measure to the understanding of the problems and policies of other countries. Eligibility: Open to graduates of any Canadian university who propose to engage in postgraduate studies in the given fields in the US or the UK.

Level of Study: Postgraduate

Type: Scholarship

Value: Canadian $\$ 10,500$ (value is subject to change)

Length of Study: 1 year, non-renewable

Frequency: Annual

Study Establishment: Suitable institutions

Country of Study: United Kingdom or United States of America

No. of awards offered: 4

Application Procedure: Applicants must complete an application form available from the website. Applications must be submitted to the Dean of Graduate Studies at the Canadian university from which the candidate most recently graduated.

Closing Date: January 16th

Funding: Private

No. of awards given last year: 4

\section{WALT DISNEY STUDIOS}

The Writing and Directing Programs, 500 South Buena Vista Street, Burbank, CA, 91521-4016, United States of America Tel: (1) 8185606894

Email: ABCWritingFellowship@disney.com Website: www.disneyabctalentdevelopment.com

The Walt Disney Company is one of the largest media and entertainment corporations in the world. Founded on October 16th,
1923 , by brothers Walt and Roy Disney as a small animation studio, today it is one of the largest Hollywood studios and also owns 9 theme parks and several television networks, including the American Broadcasting Company (ABC).

The Walt Disney Studios and ABC Entertainment Writing Fellowship Program

Subjects: Feature film and television.

Purpose: To seek out and employ culturally and ethnically diverse new writers.

Eligibility: Open to all writers.

Level of Study: Professional development

Type: Fellowships

Value: Fellows will each be provided a salary of $\$ 50,000$ for a 1 -year period tentatively

Length of Study: 1 year

Frequency: Annual

No. of awards offered: Up to 15

Application Procedure: Applicants can download the application form from the website.

Closing Date: June 23rd

Additional Information: Members with Writers Guild of America (WGA) credits are also eligible for this programme and can apply via Employment Access Department at 3237824648.

\section{THE WARBURG INSTITUTE}

University of London, Woburn Square, London, WC1H OAB, England Tel: (44) 02078628949 Fax: (44) 02078628955

Email: warburg@sas.ac.uk Website: http://warburg.sas.ac.uk/home/ Contact: Administrative Assistant

The Warburg Institute is concerned mainly with cultural history, art history and history of ideas, especially in the Renaissance. It aims to promote and conduct research on the interaction of cultures, using verbal and visual materials. It specializes in the influences of ancient Mediterranean traditions on European culture from the Middle Ages to the modern period.

\section{Albin Salton Fellowship}

Subjects: Cultural and intellectual history that led to the formation of a new worldview, understood in the broadest cultural, political and socioeconomic terms as Europe developed contacts with the world in the late medieval, renaissance and early modern periods and that world came into contact with Europe.

Purpose: To enable a young scholar to spend 2-4 months at the Warburg Institute, pursuing research.

Eligibility: Fellowships are generally for young scholars in the early stages of their career; Candidates may be pre- or postdoctorates, but must have completed at least 1 year of research on their doctoral dissertation by the time they apply. Postdoctoral candidates, must normally have been awarded their doctorate within the preceding five academic years. If it was awarded before, then they should explain the reasons for any interruption in their academic career in a covering letter.

Level of Study: Doctorate, Postdoctorate

Type: Research fellowship

Value: $£ 2,500$ for 2 months, $£ 3,600$ for 3 months, or $£ 4,800$ for 4 months.

Length of Study: 2-4 months

Frequency: Annual

Study Establishment: The Warburg Institute, London

Country of Study: United Kingdom

No. of awards offered: 1

Application Procedure: Please fill in the application form available at http://warburg.sas.ac.uk/fellowships/short-term/\#c2549 and email it to warburg@sas.ac.uk. The form asks for a research project description (800 words maximum), a curriculum vitae (up to 3 pages), and the names of 2 referees who have agreed to write, without further invitation, in support of the application.

Closing Date: November 28th

Funding: Private

No. of awards given last year: 1 


\section{Brian Hewson Crawford Fellowship}

Subjects: The classical tradition.

Purpose: To support research into any aspect of the classical tradition. Eligibility: Fellowships are generally intended for scholars in the early stages of their career. Candidates may be pre or postdoctoral, but must have completed at least 1 year of research on their doctoral dissertation by the time they submit their application. Postdoctoral candidates must normally have been awarded their doctorate within the preceding 5 years. If their doctorate was awarded before this they should explain the reasons for any interruption in their academic career in a covering letter.

Level of Study: Doctorate, Postdoctorate

Type: Fellowship

Value: $£ 2,625$ (small increase expected for 2017/18 Fellowships)

Length of Study: 2 months

Frequency: Annual

Study Establishment: The Warburg Institute, London

Country of Study: United Kingdom

No. of awards offered: 1

Application Procedure: Please fill in the application form available at http://warburg.sas.ac.uk/fellowships/short-term/\#c2549 and email it to warburg@sas.ac.uk. The form asks for a research project description ( 800 words maximum), a curriculum vitae (up to 3 pages), and the names of 2 referees who have agreed to write, without further invitation, in support of the application.

Closing Date: November 27th

Funding: Private

No. of awards given last year: 1

Additional Information: Those employed as professor, lecturer or equivalent in a university or learned institution may normally hold an award only if they are taking unpaid leave for the whole of the period. The fellowship may not be held concurrently with another fellowship or award.

\section{Brill Fellowships at CHASE}

Subjects: Any aspect of the relations between Europe and the Arab world from the Middle Ages to the 19th century.

Purpose: To carry out research on any aspect of the relations between Europe and the Arab world from the Middle Ages to the 19th century. Eligibility: The fellowships are generally intended for scholars in the early stages of their careers. Candidates must have completed at least 1-year research on their doctoral dissertation by the time they submit their application for a fellowship and, if postdoctoral, must normally have been awarded their doctorate within the preceding 5 years. If their doctorate was awarded before this date, they should explain the reasons for any interruptions in their academic career in a covering letter.

Level of Study: Postdoctorate

Type: Fellowship

Value: $£ 2,625$ for 2 months; $£ 3,780$ for 3 months (small increase expected for 2017/18 Fellowships)

Length of Study: 2 or 3 months

Frequency: Annual

Study Establishment: The Warburg Institute

Country of Study: United Kingdom

No. of awards offered: 1 or 2

Application Procedure: Please fill in the application form available at http://warburg.sas.ac.uk/fellowships/short-term/\#c2549 and email it to warburg@sas.ac.uk. The form asks for a research project description ( 800 words maximum), a curriculum vitae (up to 3 pages), and the names of 2 referees who have agreed to write, without further invitation, in support of the application.

Closing Date: November 27th

Contributor: Brill Publishing (Leiden) is sponsoring up to two annual research fellowships which have been made possible by the Sheikh Zayed Book Award for publishing, which Brill won in 2012.

\section{Frances A Yates Fellowships}

Subjects: Any aspect of cultural and intellectual history with emphasis on the medieval and renaissance periods. Preference will be given to those areas of knowledge to which Dame Frances made a contribution.

Purpose: To promote research in any aspect of cultural and intellectual history.

Eligibility: Fellowships are generally intended for young scholars in the early stages of their career. Candidates may be pre- or postdoctorates, but must have completed at least 1 year of research on their doctoral dissertation before they apply. Postdoctoral candidates, must normally have been awarded their doctorate within the preceding five academic years. If their doctorate was awarded earlier, they should explain the reason for any interruption in their academic career in a covering letter.

Level of Study: Postdoctorate, Doctorate

Type: Fellowship

Value: $£ 2,625$ for 2 months (Short-term); $£ 3,780$ for 3 months; $£ 5,040$ for 4 months (small increase expected for 2017/18 Fellowships) Length of Study: The long-term fellowship is $1-3$ years, not normally renewable, and short-term fellowships are 2-4 months, nonrenewable

Frequency: Annual

Study Establishment: The Warburg Institute, London

Country of Study: United Kingdom

No. of awards offered: Several short-term awards. Occasionally a long-term fellowship is offered

Application Procedure: Please fill in the application form available at http://warburg.sas.ac.uk/fellowships/short-term/\#c2549 and email it to warburg@sas.ac.uk. The form asks for a research project description ( 800 words maximum), a curriculum vitae (up to 3 pages), and the names of 2 referees who have agreed to write, without further invitation, in support of the application.

Closing Date: November 27th

Funding: Private

No. of awards given last year: 7 (short-term)

\section{Grete Sondheimer Fellowship}

Subjects: Any aspect of cultural and intellectual history with the emphasis on the medieval and renaissance period.

Purpose: To promote research in any aspect of cultural and intellectual history.

Eligibility: The fellowships are generally intended for scholars in the early stages of their careers. Candidates must have completed at least 1 year research on their doctoral dissertation by the time they submit their application for a fellowship and, if postdoctoral, must normally have been awarded their doctorate within the preceeding 5 years. If their doctorate was awarded before this date, they should explain the reasons for any interruptions in their academic career in a covering letter.

Level of Study: Doctorate, Postdoctorate

Type: Fellowship

Value: $£ 2,625$ (small increase expected for 2017/18 Fellowships)

Length of Study: 2 months

Frequency: Annual

Study Establishment: The Warburg Institute, London

Country of Study: United Kingdom

No. of awards offered: 1

Application Procedure: Please fill in the application form available at http://warburg.sas.ac.uk/fellowships/short-term/\#c2549 and email it to warburg@sas.ac.uk. The form asks for a research project description ( 800 words maximum), a curriculum vitae (up to 3 pages), and the names of 2 referees who have agreed to write, without further invitation, in support of the application.

Closing Date: November 27th

Funding: Private

No. of awards given last year: 1

\section{Henri Frankfort Fellowship}

Subjects: The intellectual and cultural history of the ancient Near East, with reference to society, art, architecture, religion, philosophy and science; the relations between the cultures of Mesopotamia, Egypt and the Aegean, and their influence on later civilizations. Purpose: To promote research into the history of the ancient near east.

Eligibility: Fellowships are generally intended for young scholars in the early stages of their career. Candidates may be pre- or postdoctorates, but must have completed at least 1 year of research on their doctoral dissertation before they apply. Postdoctoral candidates must normally have been awarded their doctorate within the preceding five academic years. If their doctorate was awarded before this, candidates should explain the reason for any interruption in their academic career in a covering letter. Please visit www. warburg.sas.ac.uk/fellowships for full details. 
Level of Study: Doctorate, Postdoctorate

Type: Fellowship

Value: $£ 2,625$ for 2 months; $£ 3,780$ for 3 months, (small increase expected for 2017/18 Fellowships)

Length of Study: 2 months

Frequency: Annual

Study Establishment: The Warburg Institute, London

Country of Study: United Kingdom

No. of awards offered: 1

Application Procedure: Please fill in the application form available at http://warburg.sas.ac.uk/fellowships/short-term/\#c2549 and email it to warburg@sas.ac.uk. The form asks for a research project description (800 words maximum), a curriculum vitae (up to 3 pages), and the names of 2 referees who have agreed to write, without further invitation, in support of the application.

Closing Date: December 27th

Funding: Private

No. of awards given last year: 1

\section{WARWICK BUSINESS SCHOOL}

\author{
University of Warwick, Coventry, CV4 7AL, England \\ Tel: (44) 2476524306 \\ Fax: (44) 2476523719 \\ Email: enquiries@wbs.ac.uk \\ Website: www.wbs.ac.uk \\ Contact: Mr Alex Keeline, Marketing Manager
}

Warwick Business School is an international school with 330 staff and 4,500 students from 130 countries worldwide, and is accredited with management associations in North America, Europe and the United Kingdom. Its high-calibre research feeds into top-quality teaching on undergraduate, specialist Master's, doctoral, and MBA degrees.

\section{ESRC Awards (For Doctoral Study)}

Subjects: Finance, industrial, employment relations, knowledge management and networks, information systems and management, marketing, strategy and operational research. See the ESRC website for up-to-date details.

Purpose: To allow the candidates to pursue the WBS Doctoral Programme.

Eligibility: Open to students applying for entry into the full-time WBS Doctoral Programme subject to the research being relevant. Home students (tuition fees plus stipend) and EU students (tuition fees only). Level of Study: Doctorate

Value: All tuition fees and stipend set at UK Research Council. Refer to the Warwick Business School website for further details

Length of Study: 3 years (full-time)

Frequency: Annual

Study Establishment: Warwick Business School

Country of Study: United Kingdom

No. of awards offered: 3

Application Procedure: Via online application system.

Closing Date: July 31st

Funding: Government

No. of awards given last year: 3

\section{ESRC PhD in Finance}

Subjects: Finance.

Purpose: To allow candidates to pursue the WBS Doctoral Programme.

Eligibility: Open to students applying for entry into the full-time

Warwick Business School PhD in Finance programme.

Level of Study: Doctorate

Value: Studentships will cover fees and a maintenance grant

Frequency: Annual

Study Establishment: Warwick Business School

Country of Study: United Kingdom

No. of awards offered: ESRC Quota awards

Application Procedure: Procedures vary according to the scholarship relevant to the area of interest.

Closing Date: January 12th

Funding: Government

Additional Information: Please check ESRC website for latest updates.
Warwick Business School PhD in Finance Scholarships (For Doctoral Study)

Subjects: Finance.

Purpose: To allow candidates to pursue the WBS Doctoral

Programme.

Eligibility: Open to students applying for entry into the full-time

Warwick Business School PhD in Finance programme.

Level of Study: Doctorate

Value: Approx. $£ 17,500$ per year. Refer the Warwick Business School website for further details

Length of Study: 4 years (full-time)

Study Establishment: Warwick Business School

Country of Study: United Kingdom

No. of awards offered: 3

Application Procedure: All applicants will be considered subject to receiving no other scholarship.

Closing Date: July 31st may consider strong applications after the deadline

No. of awards given last year: 3

\section{Warwick Business School Scholarships \\ (For Doctoral Study)}

Subjects: Finance, industrial, employment relations, knowledge management, networks, operational research, information systems and management, marketing, and strategy.

Purpose: To allow candidates to pursue the WBS Doctoral Programme.

Eligibility: Open to students applying for entry into the full-time

Warwick Doctoral Programme, subject to research area being

relevant.

Level of Study: Doctorate

Type: Bursary and scholarship

Value: Approx. $£ 17,500$ per year. Refer to the Warwick Business

School website for further details

Length of Study: 4 years (full-time)

Study Establishment: Warwick Business School

Country of Study: United Kingdom

No. of awards offered: 5

Application Procedure: All applicants will be considered subject to receiving no other scholarship.

Closing Date: July 31st may consider strong applications after the deadline

No. of awards given last year: 5

\section{Warwick Business School Scholarships}

(For Executive MBA)

Subjects: Warwick Executive MBA.

Purpose: To allow candidates to pursue the Warwick Executive MBA course.

Eligibility: Open to all applicants applying for the Warwick Executive MBA.

Level of Study: MBA

Type: Scholarship

Value: The scholarships provide up to 50 per cent of the annual tuition

fee (for the first year only)

Length of Study: 2.5-3 years

Study Establishment: Warwick Business School

Country of Study: United Kingdom

No. of awards offered: 14

Application Procedure: All applicants to the programme will automatically be considered for the scholarship.

Closing Date: Please see the website

No. of awards given last year: 6

\section{Warwick Business School Scholarships (For Full-Time MBA Study)}

Subjects: MBA by full-time study.

Purpose: To allow candidates to pursue the Warwick MBA course.

Eligibility: Open to students applying for full-time.

Level of Study: MBA, Professional development

Type: Scholarship

Value: The scholarships provide up to 50 per cent of the tuition fees, up to a maximum of UK£12,000 for full-time MBA applicants

Length of Study: 1 year 
Study Establishment: Warwick Business School Country of Study: United Kingdom

No. of awards offered: 25

Application Procedure: All applicants to the programme will automatically be considered for the scholarship.

Closing Date: July 31st

No. of awards given last year: 22

\section{Warwick Business School Scholarships \\ (For Global Energy MBA)}

Subjects: Warwick Global Energy MBA.

Purpose: To allow candidates to pursue the Warwick Global Energy MBA.

Eligibility: Open to all students applying for Global Energy MBA.

Level of Study: MBA

Type: Scholarship

Value: The scholarships provide up to 50 per cent of the tuition fees, (for the first year only) up to a maximum of UK£10,400

Length of Study: 3 years

Study Establishment: Warwick Business School

Country of Study: United Kingdom

No. of awards offered: 4

Application Procedure: All applicants to the programme will automatically be considered for the scholarship.

Closing Date: March 5th

No. of awards given last year: 2

\section{Warwick Business School Scholarships \\ (For Masters Study)}

Subjects: Finance and economics, management, financial maths, marketing and strategy, international employment relations, information systems management and innovation management science and operational research, business analytics and consulting, management and organizational analysis, industrial relations and managing human resources, accounting and finance, and finance.

Purpose: To allow candidates to pursue full-time and part-time specialist Masters courses.

Eligibility: Open to homely students applying for full-time and part-time masters courses. Please refer to the website for eligibility criteria.

Level of Study: Postgraduate

Type: Scholarship

Value: UK£2,500-10,000

Length of Study: 1 year (full-time), 2 years (part-time)

Frequency: Annual

Study Establishment: Warwick Business School

Country of Study: United Kingdom

No. of awards offered: Varies

Application Procedure: All applicants to the courses will automatically be considered for the scholarships.

Closing Date: Rolling admissions

No. of awards given last year: 35

Additional Information: Please refer to the website for details.

\section{Warwick Business School Scholarships}

(For MBA Study via Distance Learning)

Subjects: MBA by distance learning.

Purpose: To allow candidates to pursue the distance-learning MBA course.

Eligibility: All self-funding candidates for distance learning applying for the programme are eligible.

Level of Study: MBA

Type: Scholarship

Value: Up to 50 per cent of the annual tuition fee (for the first year only)

Length of Study: $2.5-3$ years

Study Establishment: Warwick Business School

Country of Study: United Kingdom

No. of awards offered: 16

Application Procedure: All applicants to the Distance Learning MBA will automatically be considered.

Closing Date: Please see the website

\section{WASHINGTON UNIVERSITY}

Graduate School of Arts and Sciences, Box 1186, 1 Brookings Drive, St Louis, MO, 63130-4899, United States of America

$$
\text { Tel: (1) } 3149355000
$$$$
\text { Fax: (1) } 3149353929
$$

Email: graduateartsci@wustl.edu

Website: graduateschool.wustl.edu

Contact: Dr Nancy P Pope, Associate Dean

Washington University has a diverse offering of events, disciplines, people, and resources that create unlimited possibilities for discovery and growth. Arts \& Sciences signals a curriculum and place, a core of teaching, learning, and discovery at Washington University.

\section{Mr and Mrs Spencer T Olin Fellowships for Women}

Subjects: Architecture, arts and humanities, business, engineering, mathematics and science.

Purpose: To encourage women of exceptional promise to prepare for professional careers.

Eligibility: Open to female graduates of a baccalaureate institution in the US who plan to prepare for a career in higher education or the professions. Applicants must meet the admission requirements of their graduate or professional school at Washington University. Preference will be given to those who wish to study for the highest earned degree in their chosen field, do not already hold an advanced degree, and are not currently enrolled in a graduate or professional degree programme. Level of Study: Doctorate, Graduate

Type: Fellowship

Value: Provides full tuition remission to all candidates and living stipend for doctoral candidates

Length of Study: 1 year, renewable for up to 4 years, or until the completion of the degree programme, whichever comes first, subject to satisfactory academic progress

Frequency: Annual

Study Establishment: Washington University

Country of Study: United States of America

No. of awards offered: Approx. 12

Application Procedure: Applicants must complete an online application. Finalists must be interviewed on campus at the expense of the University.

Closing Date: January 25th

Funding: Private

Contributor: The Monticello College Foundation

No. of awards given last year: 13

No. of applicants last year: 351

Additional Information: Candidates must also make concurrent application to the department or school of Washington University in which they plan to study.

\section{Washington University Chancellor's Graduate Fellowship Program}

Subjects: Arts and sciences, business, engineering and social work. Purpose: To encourage students who are interested in becoming college or university professors, and who bring diversity to the campus environment.

Eligibility: Open to graduates of a U.S. baccalaureate institution who plan to prepare for a career in the professoriate. Applicants must meet admission requirements of their graduate or professional school at

Washington University, and provide evidence that they will contribute to diversity on our campus.

Level of Study: Doctorate, Graduate

Type: Fellowship

Value: All candidates provided full tuition remission, living stipend, and educational allowance

Length of Study: 5 years, subject to satisfactory academic progress Frequency: Annual

Study Establishment: Washington University

Country of Study: United States of America

No. of awards offered: $6-8$

Application Procedure: Applicants must complete an ONLINE application. Finalists must be interviewed on campus at the expense of the University.

Closing Date: January 25th

No. of awards given last year: 10

No. of applicants last year: 145 
Additional Information: The fellowship includes other Washington University programmes providing final disciplinary training for prospective college professors.

\section{THE WELDER WILDLIFE FOUNDATION}

PO Box 1400, Sinton, TX, 78387, United States of America Tel: (1) 3613642643

Fax: (1) 3613642650

Email: welderfoundation@welderwildlife.org

Website: www.welderwildlife.org

Contact: Terry Blankenship, Director

The Welder Wildlife Foundation is a private, non-profit foundation established in 1954. The Foundation has gained international recognition through its research programme. The primary purpose of the Foundation is to conduct research and education in the field of wildlife management and conservation and other closely related fields. As a private foundation their purpose and operation remain unhindered by outside political or institutional pressures.

\section{Rob and Bessie Welder Wildlife Foundation's Graduate Research Scholarship Program}

Subjects: Animal behaviour, biology, botany, conservation education, ecology, mammalogy, ornithology, parasitology, range science, veterinary pathology and wildlife sciences.

Purpose: To conduct research and education in the field of wildlife management and conservation and other closely related fields. Eligibility: Applicant must have a minimum GRE score of 1,100 and 3.0 GPA in the last 2 years of undergraduate or graduate work. Level of Study: Doctorate, Master of Science

Type: Scholarship

Value: $\$ 1,300$ per month for full-time M.S. candidates and $\$ 1,400$ per month for full-time Ph.D. candidates to cover living costs, tuition, fees, and books.

Frequency: Annual

Country of Study: United States of America

Application Procedure: Applications and abbreviated proposals may be submitted in letter form and must be signed by a qualified member of the faculty at the parent university.

Closing Date: October 1st

Funding: Foundation, private

No. of awards given last year: 2

No. of applicants last year: 10

\section{WELLBEING OF WOMEN}

First floor, Fairgate House, 78 New Oxford Street, London, WC1A 1HB, England Tel: (44) 02936977000

Email: hello@wellbeingofwomen.org.uk Website: www.wellbeingofwomen.org.uk

Contact: Mrs Philip Matusavage, Research Manager

Wellbeing of Women is the only UK charity funding vital research into all aspects of reproductive health in three key areas; gynaecological cancers, pregnancy and birth, and quality of life problems.

\section{Wellbeing of Women Entry-Level Scholarship}

Subjects: All subjects of relevance to women's health.

Purpose: To provide Pump-Priming funds to enable trainees to be exposed to a research environment to obtain pilot data for bids for definitive funding.

Eligibility: Work must be undertaken in the UK or Ireland.

Applications must be from individuals who have not previously been involved in substantial research projects.

Level of Study: Graduate, Postgraduate

Type: Scholarship

Value: A maximum of UK£20,000

Length of Study: $1-3$ years

Frequency: Annual

Study Establishment: A hospital or university.

Country of Study: United Kingdom, Republic of Ireland

No. of awards offered: Varies depending on the amount of disposable income
Application Procedure: Applicants must write for details or access the website.

Closing Date: September

Funding: Commercial, individuals, private, trusts

No. of awards given last year: 4

No. of applicants last year: 16

\section{Wellbeing of Women Project Grants}

Subjects: All subjects of relevance to women's health.

Purpose: To fund research projects.

Eligibility: Open to specialists in any obstetrics/gynaecology interrelated field.

Level of Study: Postdoctorate, Research

Type: Grant

Value: A maximum of UK£200,000 over 3 years

Length of Study: $1-3$ years

Frequency: Annual

Study Establishment: A hospital or university

Country of Study: United Kingdom, Republic of Ireland

No. of awards offered: Varies depending on the amount of disposable income

Application Procedure: Applicants must write for details or access the website.

Closing Date: February

Funding: Commercial, individuals, private, trusts

No. of awards given last year: 3

No. of applicants last year: 59

\section{Wellbeing of Women Research Training Fellowship}

Subjects: All subjects of relevance to women's health.

Purpose: To fund training in basic science or clinical research techniques and methodology for a medical graduate embarking upon a career in obstetrics and gynaecology.

Eligibility: Research training fellowships are to be undertaken in the UK or Ireland.

Level of Study: Research, Postdoctorate, Postgraduate

Type: Fellowship

Value: The upper limit for this award is UK£200,000

Length of Study: $1-3$ years

Frequency: Annual

Study Establishment: A hospital or university.

Country of Study: United Kingdom, Republic of Ireland

No. of awards offered: Varies depending on the amount of

disposable income

Application Procedure: Applicants must write for details or access the website.

Closing Date: September

Funding: Commercial, individuals, private, trusts

No. of awards given last year: 1

No. of applicants last year: 16

\section{WELLCHILD INTERNATIONAL}

16 Royal Crescent, Cheltenham, Gloucester, GL50 3DA, England Tel: (44) 1242530007

Fax: (44) 1242530008

Email: info@wellchild.org.uk

Website: www.wellchild.org.uk

Contact: The Administrator

WellChild is committed to getting sick children better, whatever their illness, through care, support and research.

\section{WellChild Pump-Priming Grants}

Subjects: Diseases in children.

Purpose: To enable a student to run a pilot study.

Level of Study: Postgraduate, Postdoctorate, Doctorate

Type: Grant

Value: Up to UK£30,000

Frequency: Annual

Study Establishment: Accredited institute in the United Kingdom

Country of Study: United Kingdom

Application Procedure: Applicants must download application and guidelines from the website.

Closing Date: September 26th 
Funding: Private

Additional Information: Assessment by peer review and the Scientific Medical Advisory Committee.

\section{WellChild Research Fellowships}

Subjects: Diseases in children.

Purpose: To support clinicians working towards the development of their own research projects.

Level of Study: Postgraduate, Doctorate, Postdoctorate

Type: Fellowship

Value: $£ 183,500$

Length of Study: Up to 3 years

Frequency: Annual

Study Establishment: Accredited institute in the United Kingdom

Country of Study: United Kingdom

Application Procedure: Applicants must download application and

guidelines from the website.

Closing Date: September 26th

Funding: Private

Additional Information: Assessment by peer review and the

Scientific Medical Advisory Committee.

\section{WELLCOME TRUST}

215, Euston Road, London, NW1 2BE, England

Tel: (44) 2076112020

Fax: (44) 2076118545

Email: grantenquiries@wellcome.ac.uk, investigators@wellcome.ac.uk

Website: www.wellcome.ac.uk

The Wellcome Trust's mission is to foster and promote research with the aim of improving human and animal health. The Trust funds most areas of biomedical research and funds research in the history of medicine, biomedical ethics, public engagement of science.

\section{Arts Awards}

Subjects: The scheme aims to: stimulate interest, excitement and debate about biomedical science through the arts; examine the social, cultural, and ethical impact of biomedical science; support formal and informal learning; encourage new ways of thinking; encourage high quality interdisciplinary practice and collaborative partnerships in arts, science and/or education practice. All art forms are covered by the programme: dance, drama, performance arts, visual arts, music, film, craft, photography, creative writing or digital media. The Trust invites applications for projects which engage adult audiences and/or young people.

Purpose: Arts Awards support imaginative and experimental arts projects that investigate biomedical science.

Eligibility: The scheme is open to a wide range of people including, among others, artists, scientists, curators, filmmakers, writers, producers, directors, academics, science communicators, teachers, arts workers and education officers. Applicants are usually affiliated to organizations, but can apply as individuals. Organizations might include: museums and other cultural attractions; arts agencies; production companies; arts venues; broadcast media; schools; local education authorities; universities and colleges; youth clubs; community groups; research institutes; the NHS; and science centres. Partnership projects (between different people and organizations, e.g. scientists and ethicists, educators and artists) are welcomed. If this is the first time an organization is applying to the Wellcome Trust an eligibility assessment will be carried out. For this assessment, the following documentation from the applying organization should be submitted: articles of association; audited accounts from the previous 2 years; details of similar projects/grant funding received; confirmation that no funding has been received or is scheduled to be received from any tobacco company.

Level of Study: Research

Type: Award

Value: Funding can be applied for at two levels: (1) Small to mediumsized projects (up to and including $£ 40,000$ ). This funding can either be used to support the development of new project ideas, deliver small-scale productions or workshops, investigate and experiment with new methods of engagement through the arts, or develop new collaborative relationships between artists and scientists and (2) Large projects (above $£ 40,000$ ). This funding can be used to fund full or part production costs for large-scale arts projects that aim to have significant impact on the public's engagement with biomedical science. We are also interested in supporting high-quality, multiaudience, multi-outcome projects. Applicants can apply for any amount within the above boundaries, for projects lasting a maximum of 3 years

Frequency: Annual

Application Procedure: Application form for awards up to and including $£ 40,000$, preliminary application form for awards over $£ 40,000$.

Closing Date: For small to medium-sized projects (up to and including $£ 40,000$ ) deadlines are February 28th, June 27th, and November 7 th. For large projects (above $£ 40,000$ ) the deadline is January 24th. For detail information check website

Funding: Trusts

Additional Information: Applicants must be based in the UK or the Republic of Ireland and the activity must take place in the UK or the Republic of Ireland.

For further information contact:

Tel: 02076115757

Email: PEgrants@wellcome.ac.uk

\section{Broadcast Development Awards}

Subjects: Funds individuals and organizations with brilliant earlystage ideas for TV, radio or new media projects. The funding will enable these ideas to be developed into high impact, well-researched proposals to be utilized in securing a broadcast platform and/or further funding. A successful project would primarily be aimed at a mainstream UK and/or Republic of Ireland audience in the first instance, although the subject matter can be international.

Purpose: To support the development of broadcast proposals in any genre that engages the audience with issues around biomedical science in an innovative, entertaining and accessible way.

Eligibility: The proposal must primarily be aimed at a mainstream UK and/or Republic of Ireland audience in the first instance but the subject matter can be international. Applicants are usually affiliated to organizations, but can apply as individuals. The scheme is open to broadcast professionals and other organizations or individuals working on broadcast projects. Partnership between broadcasters and other professionals such as scientists, ethicists, educators etc. are especially welcomed.

Level of Study: Research

Type: Award

Value: Up to $£ 10,000$, for a maximum of 1 year

Length of Study: 1 year

Frequency: Biannual

Application Procedure: Candidates should complete and submit an application form by the published deadline.

Closing Date: Refer website

Funding: Trusts

Additional Information: Applicants must be based in the UK or the Republic of Ireland, although other members of the project team can be based overseas.

For further information contact:

Tel: 02076115757

Email: PEgrants@wellcome.ac.uk

\section{Career Re-entry Fellowships}

Subjects: Biomedical Science.

Purpose: This scheme is for postdoctoral scientists who have recently decided to recommence a scientific research career after a continuous break of at least 2 years.

Eligibility: The awards are open to individuals with a relevant connection to the European Economic Area (EEA). You should be a research scientist with at least 2 years' postdoctoral experience and intend to be based in a UK or Republic of Ireland organization. You must have had a continuous career break of at least 2 years and should have either a strong research track record (if applying for up to 4 years' support) or demonstrated the potential for a strong research career prior to your break (if applying for 2 years' support). A 2-year fellowship should provide sufficient training support to consolidate your potential. The proposed research should fall within the Wellcome 
Trust's normal funding remit. Resubmissions are not normally encouraged. If your application has been unsuccessful, please contact the Office for advice. You must have an eligible sponsoring laboratory in the UK or Republic of Ireland that will administer the fellowship for the duration of the award

Level of Study: Professional development

Type: Fellowship

Value: It provides support that includes the fellow's salary, as determined by the host institution with an additional Trust enhancement, and Research expenses (consumables, animals, travel support to attend scientific meetings)

Length of Study: 2-4 years

Frequency: Biannual

Application Procedure: A preliminary application form (Word 92kB) should be completed and submitted by the published deadline. It should be sent electronically (as a Word document), with the requested accompanying information, to the appropriate funding stream at the Trust (see website). If successful, you will be shortlisted for interview.

Closing Date: May 15th, 5pm (preliminary applications); July 17th, 5pm (full applications); and November 11th-13th (shortlisted candidate interviews)

Funding: Trusts

Additional Information: For further information visit www.wellcome. ac.uk/Funding/Biomedical-science/Funding-schemes/Fellowships/ Basic-biomedical-fellowships/wtd004380.htm

\section{For further information contact:}

Tel: 02076115757

Email: sciencegrants@wellcome.ac.uk

\section{Clinical PhD Programmes}

Subjects: Biomedical science.

Purpose: This is a flagship scheme aimed at supporting the most promising medically qualified clinicians who wish to undertake rigorous research training.

Eligibility: You should have demonstrated the potential to pursue a career as an academic clinician. It is anticipated that many applicants will have already commenced their specialist training, but this is not essential.

Level of Study: Postgraduate, Research

Type: Grant

Value: The duration may vary from Programme to Programme, but each provides a clinical salary, PhD registration fees at UK/EU student rate, research expenses, contribution towards travel and contribution towards general training costs

Frequency: Annual

No. of awards offered: 7

Application Procedure: Students are recruited annually by the individual Programmes. Recruitment begins in the preceding January. If you are interested in applying you should contact the relevant Programme directly. Please see website for more details.

Closing Date: Varies

Funding: Trusts

For further information contact:

Email: clinicalphd@wellcome.ac.uk or j.williams@wellcome.ac.uk

\section{Doctoral Studentships}

Subjects: Medical history and humanities.

Purpose: This scheme enables scholars to undertake up to 3 years of full-time research on a history of medicine topic leading to a doctoral degree at a university in the UK or Republic of Ireland.

Eligibility: You should hold a Master's in the history of medicine or a Master's with strong emphasis on the history of medicine. The proposed project must be on a history of medicine topic. If specialist language skills are essential to undertake the research, a Master's in the language required may be acceptable (classical languages, Arabic, Chinese, etc.). Your application must be sponsored by a senior member of the department, unit or institute, or History of Medicine grantholder (current or former), who would supervise you if an award were made. Applications must be submitted through the host institution.

Level of Study: Postgraduate, Research
Value: Support is provided for up to 3 years, and includes: the student's stipend; a set amount to cover conference travel, research expenses and, where justified, the cost of overseas fieldwork; all compulsory university and college fees at the UK/Irish/Dutch home postgraduate student level; fees at the overseas rate will not be provided; institutions sponsoring candidates are expected to provide laptops and PCs as part of their postgraduate research-training infrastructure

Length of Study: 3 years

Application Procedure: Preliminary applications should be made by email or post by the published deadline, and should include: a brief curriculum vitae with details of the Master's degree held; details of the research proposed (maximum of one page); a letter of support from the head of the department in which you will be working (this can be sent under separate cover); a letter of support from the supervisor. Closing Date: April 2nd

Funding: Trusts

For further information contact:

Tel: 02076115757

Email: MHgrants@wellcome.ac.uk

\section{Four-year PhD Studentship Programmes}

Subjects: Biomedical science.

Purpose: This is a flagship scheme aimed at supporting the most promising students to undertake in depth postgraduate training. Supporting specialized training provided in a range of important biomedical research areas: (1) developmental biology and cell biology; (2) genetics, statistics and epidemiology; (3) immunology and infectious disease; (4) molecular and cellular biology; (5) neuroscience; (6) physiological sciences; (7) structural biology and bioinformatics.

Eligibility: You should be a student who has, or expects to obtain, a first- or upper-second-class honours degree or equivalent.

Level of Study: Postgraduate, Research

Value: A stipend, $\mathrm{PhD}$ registration fees at UK/EU student rate, contribution towards laboratory rotation expenses in the first year, research expenses for years two to four, contribution towards travel and contribution towards transferable-skills training

Length of Study: Support provided for 4 years

Frequency: Various

No. of awards offered: Support 32 Programmes based in centres of excellence throughout the UK

Application Procedure: Students are recruited annually by the individual Programmes for uptake in October each year. Recruitment begins in the preceding December. If you are interested in applying you should contact the relevant Programme directly. Please see website for details.

Closing Date: October

Funding: Trusts

\section{For further information contact:}

Email: 4yrphd@wellcome.ac.uk

\section{Health Innovation Challenge Fund}

Purpose: This is a 5-year parallel funding partnership between the Wellcome Trust and the Department of Health to stimulate the creation of innovative healthcare products, technologies and interventions, and facilitate their development for the benefit of patients in the NHS and beyond.

Eligibility: Please note that the 'Lead applicant' for all HICF awards must be a U.K. organization or company. The following types of organization (singly or in collaboration) will be eligible for funding: NHS organizations (including NHS Trusts and NHS Foundation Trusts), and equivalent U.K. authorities; universities, and research institutes and not-for profit organizations; start-up companies founded to capture and develop intellectual property of relevance to healthcare; biotechnology, pharmaceutical, bioinformatics, engineering or other companies. A collaboration between two or more of the entities detailed above is also eligible and encouraged where it strengthens the overall proposal.

Type: Award

Application Procedure: Applicants should submit a preliminary application (see the forms and guidance tab on this page) including the following information: an outline of the work packages that are to 
be undertaken using Wellcome Trust/Department of Health funding including details of specific milestones, objectives and deliverables; current validation of the concept, how it addresses a medical need, position on patient management pathway or disease algorithm; downstream route to launch, market introduction and adoption; sensitivity or risk analysis for the major hurdles; an overview of intellectual property and regulatory approval issues; eventual financial sustainability of the product line; an approximate breakdown of costs; justification for requesting Wellcome Trust/Department of Health funds, if the applicant is a company; details of all information which an applicant considers commercially sensitive or confidential.

Closing Date: September 15th (Preliminary application); October 17th (Shortlisting of proposals); January 12th (Full applications submitted); April 12th (Funding decisions)

Funding: Trusts

Additional Information: The Health Innovation Challenge Fund (HICF) is a $£ 100,000,000,5$-year parallel funding partnership between the Wellcome Trust and the Department of Health. The funders are collaborating to stimulate the creation of innovative healthcare products, technologies and interventions, and facilitate their development for the benefit of patients in the NHS and beyond. The HICF will have a succession of thematic calls for proposals, each selected to focus on unmet needs in healthcare relevant to the NHS, and will support innovative developments that are within three to 5 years of launch or adoption.

\section{Integrated Training Fellowships for Veterinarians \\ Subjects: Biomedical science.}

Purpose: This scheme provides support for veterinary graduates and undergraduates to develop a career in veterinary research, by providing funding to obtain a $\mathrm{PhD}$ and continue clinical training towards a relevant clinical certificate, diploma or postgraduate pathology qualification. The $\mathrm{PhD}$ should be laboratory based and may be undertaken within the veterinary school, but applications are particularly encouraged where the $\mathrm{PhD}$ is based in, or involves collaboration with, a basic biomedical science laboratory.

Eligibility: You must have completed, or be about to complete, a first degree in veterinary medicine or veterinary science (e.g. BMedVet, BMedSci, VetMB). An intercalated BSc is desirable and some experience in clinical practice, together with evidence of an ongoing interest in a research career, such as project work and/or summer school attendance, would also be advantageous. You are expected to undertake a research project that balances the provision of training with the opportunity to advance knowledge in a given area. Under this scheme, there is also the possibility of support for PhDs to be held during an undergraduate veterinary degree. Support for post graduation clinical training can also be provided. Please talk to your course supervisor in the first instance and then contact the Trust to discuss further. The awards are open to individuals with a relevant connection to the European Economic Area.

Level of Study: Postgraduate, Research

Type: Fellowship

Value: (1) A basic salary as determined by the host institution

(2) Research expenses for 3 years (consumables, small pieces of equipment, animals where necessary) (3) Training (requests must be justified) (4) A travel allowance to attend scientific meetings (this is automatically provided as part of an award)

Length of Study: Up to 6 years

Frequency: Annual

Application Procedure: A preliminary application form should be completed and submitted by the published deadline. An electronic copy of the form (as a Word document) and each accompanying document should be emailed to vets@wellcome.ac.uk. One hard copy of the form (including signatures), should be sent to our postal address, marked for the attention of Veterinary Fellowships. Please note that all Word documents will need to be sent in Word 2003 (or an earlier version). Successful candidates will be invited to submit a full application, to be returned to the Trust no later than the published deadline.

Closing Date: September 1st

Funding: Trusts

\section{Intermediate Clinical Fellowships}

Subjects: Biomedical science.

Purpose: This scheme is for medical, dental, veterinary or clinical psychology graduates who have had an outstanding start to their research career. It will enable successful candidates to continue their research interests at a postdoctoral level in an appropriate unit or clinical research facility.

Eligibility: The award is open to individuals with a relevant connection to the EEA. You should have previously undergone a period of research training and will have completed, or be about to complete, a higher degree. You should have completed general professional training as defined by the relevant college. (1) Medical and dental candidates should either have a National Training Number (NTN) or Certificate of Completion of Specialist Training (CCST) or equivalent. (2) Veterinary candidates should have a degree in veterinary medicine (e.g. BVSc, BVM\&S, BVMS, BVetMed, VetMB) and some experience in clinical practice and will have completed, or be about to complete, a higher research degree (preferably a PhD). (3) GPs are advised to contact the office to clarify their eligibility. (4) Clinical Psychologists must have obtained a professional Doctorate-level qualification in Clinical Psychology accredited by the British Psychological Society. Level of Study: Postgraduate, Research

Type: Fellowship

Value: Fellowships are for up to 4-5 years, depending on situation. They provide research expenses (consumables, travel, support to attend scientific meetings) and the fellow's salary, set by the host institution according to age and experience. Requests for specific items of equipment, where relevant, may be considered, and research or technical assistance may be requested. However, a laboratory appropriate to the research proposed should be selected, and the necessary facilities required for the proposed research must be available to the candidate. Funding for a period of research abroad may be requested if scientifically justified, and we provide appropriate allowances for fellows based overseas

Frequency: Annual

Application Procedure: A preliminary application form [Word 161kB] should be completed and submitted at any time before the appropriate deadline. It should be sent electronically (as a Word document) to the appropriate funding stream at the Trust (see website). If your preliminary application is successful, you will be invited to submit a full application by the published deadline. This will be peer reviewed and considered by the relevant Funding Committee. Shortlisted candidates will subsequently be invited to attend for interview at the Trust. Closing Date: March 8th; please visit the following link for full details: www.wellcome.ac.uk/Funding/Biomedical-science/Funding-schemes/ Fellowships/Clinical-fellowships/wtd004402.htm.

Funding: Trusts

\section{For further information contact:}

Tel: 02076115757

Email: sciencegrants@wellcome.ac.uk

\section{Intermediate Fellowships in Public Health and Tropical Medicine}

Subjects: Biomedical science.

Purpose: This scheme enables high-calibre, mid-career researchers from low- and middle-income countries to establish an independent research programme. Fellows must be based primarily in a low- and middle-income country. Research projects should be aimed at understanding and controlling diseases (either human or animal) of relevance to local, national or global health. This can include laboratory based molecular analysis of field or clinical samples, but projects focused solely on studies in vitro or using animal models will not normally be considered under this scheme.

Eligibility: Applications are only accepted in the Public Health and Tropical Medicine Interview Committee remit. This covers research on infectious and non-communicable diseases within the fields of public health and tropical medicine that is aimed at understanding and controlling diseases (either human or animal) of relevance to local, national or global health. You must be a national or legal resident of a low- and middle-income country and should be either: (1) A graduate in a subject relevant to public health or tropical medicine (e.g. biomedical or social science, veterinary medicine, physics, chemistry or mathematics) with a $\mathrm{PhD}$ and 3-6 years' postdoctoral experience, or (2) A medical graduate with a higher qualification equivalent to membership of the U.K. Royal Colleges of Physicians (i.e. qualified to enter higher specialist training) or recognized as a specialist within a relevant research area, with 3-6 years' research experience. You must have a relevant high-quality publication record and show 
potential to become a future scientific leader. Applicants who do not have a PhD but who are educated to first degree or Master's level and have extensive research experience, as evidenced by their publication record, may be considered.

Level of Study: Postgraduate, Research

Type: Fellowship

Value: Fellowships are for up to 5 years (non-renewable) and provide support that includes: a basic salary for the fellow; research expenses (e.g. consumables, equipment, collaborative travel, research assistance, technical support); training costs where appropriate and justified; an inflation/flexible funding allowance and support to attend scientific meetings. Contributions to costs of the project which are directly incurred by the overseas institution may be provided

Frequency: Three times per year

Application Procedure: You must complete and submit a preliminary application form [Word $236 \mathrm{kB}$ ] by the published deadline. The form should be emailed to phatic@wellcome.ac.uk. Completed forms will normally be assessed within 1 month of the preliminary deadline. If the preliminary application meets the scheme's requirements, a full application will be invited.

Closing Date: Preliminary application deadline: May 23rd, Full application deadline: July 18th, Shortlisted candidate interviews: November 22nd-23rd

Funding: Trusts

Additional Information: For complete details please check the link www.wellcome.ac.uk/Funding/Biomedical-science/Funding-schemes/ Fellowships/Public-health-and-tropical-medicine/wtd025883.htm.

\section{For further information contact:}

Tel: 02076115757

Email: sciencegrants@wellcome.ac.uk

\section{International Engagement Awards}

Subjects: International Engagement Awards support projects that aim to achieve some or all of the following: to strengthen the capacity of people in low- and middle-income countries to facilitate public engagement with health research; to stimulate dialogue about health research and its impact on the public in a range of community and public contexts in low- and middle-income countries; to investigate and test new methods of engagement, participation, communication or education around health research; to promote collaboration on engagement projects between researchers and community or public organizations; to support Wellcome Trust funded researchers in lowand middle-income countries in engaging with the public and policy makers. Projects could involve: communities and members of the public (particularly those affected by or involved in health research); science communicators, health and science journalists; healthcare professionals, educators, field workers, community workers policy and decision makers.

Purpose: To provide funding for innovative public or community engagement projects that explore biomedical research or health in Africa and Asia and to ensure science can be enjoyed and experienced as part of culture, entertainment and everyday life. Eligibility: The scheme is open to a wide range of people, including media professionals, educators, science communicators, health professionals and researchers in bioscience, health, bioethics and history. Partnership projects (between different people and organizations, e.g. scientists and media professionals, ethicists and community workers) are welcomed. Applicants must be based in listed low- and middle-income countries or in the UK working with partners in the lowand middle-income countries. The activity must primarily take place in one or more low- and middle-income countries and the primary goal must be to involve participants or engage audiences located in lowand middle-income countries. Applicants from listed restructuring countries in Europe and Asia are not eligible. We can only accept applications in the English language but we welcome projects that bring together people from different backgrounds who speak diverse languages. All projects must involve engagement with health research. Projects dealing purely with development research not related to health are not eligible. Please note also, that the scheme is not intended to support standard delivery of health education and promotion which does not focus on health research or involve health researchers. Applicants must be affiliated to organizations or institutions. Organizations might include: media organizations, research centres or research groups, community-based development organizations, education organizations. The International Engagement Awards will not fund traditional scientist-led health research. We may consider an application for participatory health research. This is research in which participants are supported to own and shape a research process, setting their own research questions and directing the research process. This type of research should not look like a consultatory exercise or health education but should aim to be collaborative process of enquiry in which the analysis is conducted and findings can be used by all participating parties. This could lead into circular processes of research and action.

Level of Study: Research

Type: Award

Value: Up to $£ 30,000$ for projects lasting a maximum of 3 years

Frequency: Biannual

Application Procedure: Please contact the International Engagement Awards office well in advance of the deadline to request an application form and to confirm the eligibility of your project.

Closing Date: August 19th

Funding: Trusts

For further information contact:

Tel: 02076115757

Email: PEgrants@wellcome.ac.uk

\section{International Senior Research Fellowships}

Subjects: Biomedical science.

Purpose: This scheme supports outstanding researchers, either medically qualified or science graduates, who wish to establish a research career in an academic institution in selected European countries-Croatia, Czech Republic, Estonia, Hungary, Poland, Slovakian Republic and Slovakia.

Eligibility: You should have between 5 and 10 years' research experience at a postdoctoral level or clinical equivalent and have a substantial record of publications in your chosen area of research in leading international journals. Your proposed research must be conducted at an academic institution in Croatia, the Czech Republic Estonia, Hungary, Poland, Slovakia Republic or Slovenia. You need not be a national of the country in which you wish to hold the fellowship. We usually expect candidates to have spent a significant period of their postdoctoral (or equivalent) research career working outside their chosen country. However proposals can also be considered from those who have pursued successful careers entirely in-country. Applications are particularly encouraged from outstanding scientists working outside their own countries who wish to return home.

Level of Study: Postgraduate, Research

Type: Fellowship

Value: The fellowship is for 5 years, and provides: (1) A salary, set according to age, experience and the appropriate academic scales. (2) Essential costs of the research programme, including consumables, equipment, collaborative travel, research assistance and technical support if appropriate. (3) A flexible funding allowance and support to attend scientific meetings, in addition to requested essential costs.

Frequency: Annual

Application Procedure: You must complete and submit a preliminary application form [Word $218 \mathrm{kB}$ ] by the published deadline. An electronic copy of the completed form (as a Word document) should be emailed to the appropriate funding stream (see website). You will be notified in writing of your success, or otherwise, in reaching the next round of the competition. Decisions will not be available by telephone. If you are successful you will be invited to submit a full application

Closing Date: October 3rd; For complete details please visit the address www.wellcome.ac.uk/funding/biomedical-science/fundingschemes/fellowships/basic-biomedical-fellowships/wtd004442.htm. Funding: Trusts

\section{Investigator Awards}

Subjects: Biomedical science.

Purpose: To support world-class researchers who are no more than 5 years from appointment to their first academic position, but who can already show that they have the ability to innovate and drive advances in their field of study. 
Eligibility: To be eligible for an Investigator Award you must be based at an eligible higher education or research institution in the UK,

Republic of Ireland or a low- or middle-income country. You should be employed in an established academic post: a permanent, open-ended or long-term rolling contract, salaried by your host institution. You are also eligible if you have a written guarantee of an established academic post at your host institution, which you will take up by the start of the award. If you are based in a low- or middle-income country in sub-Saharan Africa, South-east Asia or South Asia (with the exception of India - see below), you are eligible to apply if you fulfil the above eligibility criteria and are working within the Trust's broad science funding remit.

\section{Level of Study: Research}

Type: Award

Value: Awards may be small or large, typically up to $£ 3,000,000$, and lasting up to 7 years. The duration and costs you request should be clearly justified by your proposed research. Also, you should ensure that the scope of your proposal and the associated resources are appropriate for your career stage and research experience. The award covers the direct costs of carrying out the research, such as: research expenses; this may include research assistance, animals, equipment, fieldwork costs and funding for collaborative activity; travel and subsistence for scientifically justified visits; overseas allowances where appropriate

Frequency: Annual

Application Procedure: The key stages of the application process are: submission of an Investigator Award application form; scientific peer review by one of the Trust's Expert Review Groups, which shortlist the candidates for interview; written peer review of shortlisted applications by external specialist referees, who will include members of the Trust's Peer Review College; selected unattributed referee comments will be fed back to candidates before interview; interview of shortlisted candidates by our Interview Panel. Application forms are available on eGrants, our electronic application system. Please refer to the Additional information for completing the Investigator Award form on eGrants, which provides an overview to help guide you through the application process

Funding: Trusts

Additional Information: The Trust has combined its New Investigator and Senior Investigator Award schemes to create a single type of Investigator Award, providing all who hold established posts in eligible organizations with the same opportunity to obtain funding.

\section{For further information contact:}

\section{Grants Information Desk}

Email: sciencegrants@wellcome.ac.uk

Website: www.wellcome.ac.uk/Funding/Biomedical-science/Fundingschemes/Investigator-Awards/WTX059284.h

Tel: 02076115757

\section{Joint Basic and Clinical PhD Studentship Programmes Subjects: Biomedical science. \\ Purpose: This is a flagship scheme aimed at supporting the most promising basic or medically qualified clinicians who wish to under- take both rigorous basic and clinical science research training. Successful candidates will develop their potential to become leading academics of the future within a structured and mentored training environment. Programmes will provide the individual trainee with opportunities to sample high-quality research environments before they develop a research proposal that is tailored to their individual interests.}

Eligibility: Basic science applicants should have, or expect to obtain, a first- or upper-second-class honours degree or equivalent. Clinically qualified candidates should have demonstrated the potential to pursue a career as an academic clinician. It is anticipated that many applicants will have already commenced their specialist training but this is not essential.

Level of Study: Postgraduate, Research

Type: Studentship

Value: A stipend for basic candidates, a clinical salary for medically qualified candidates, $\mathrm{PhD}$ registration fees at U.K./EU student rate, research expenses, contribution towards travel and contribution towards transferable-skills training

Length of Study: Support is provided for 4 years

\section{Frequency: Annual}

No. of awards offered: Two programmes have been established based in centres of excellence at Birmingham and the Institute of Cancer Research

Application Procedure: Students are recruited annually by the individual programmes. Recruitment begins in the preceding January. If you are interested in applying you should contact the relevant programme directly. Please see their website for more details.

Closing Date: January

Funding: Trusts

\section{KEMRI-Wellcome Trust-IDeAL PhD Studentships}

Subjects: Studentships are available in the following research areas: Epidemiology, molecular parasitology, immunology, neuroscience, psychology, clinical epidemiology, health economics and health systems research.

Purpose: KEMRI-Wellcome Trust Research Programme is an internationally renowned health research programme that is committed to developing research capacity in the East African Region.

Several PhD studentship positions commencing in January 2016 are available at their Kilifi and Nairobi sites. These studentships, which are funded under the Initiative to Develop African Research Leaders (IDeAL), will provide an opportunity for East Africans to carry out their $\mathrm{PhD}$ studies within a high-quality research environment under the supervision of internationally renowned researchers.

Eligibility: Applications are invited from East Africans (Kenya, Uganda, Tanzania, Rwanda, Burundi, Ethiopia) who have at least an upper second-class bachelor's degree and a master's degree in biological sciences, nursing, pharmacy, public health, social sciences, economics or at least a bachelor's degree in medicine.

Type: Fellowship

Length of Study: Studentships are awarded for pursuing PhD programme

Application Procedure: Application form is available from the website.

Closing Date: August 5th

Funding: Trusts

\section{Master's Awards}

Subjects: Medical history and humanities.

Purpose: This scheme enables scholars to undertake basic training in research and methods through a 1-year Master's course in medical history and humanities.

Eligibility: You should have a minimum of an excellent upper-secondclass honours degree (or equivalent) in a relevant subject. Applications will not be considered from those who have already received support for their postgraduate studies from another funding body. Level of Study: Research, Postgraduate

Type: Award

Value: The award is for 1 year, and includes: the student's stipend; all compulsory university and college fees at the U.K. home postgraduate student level. Fees at the overseas rate will not be provided

Frequency: Annual

Application Procedure: All enquiries about Master's Awards should be made directly to the relevant institution.

Closing Date: May 1st

Funding: Trusts

For further information contact:

Tel: 02076115757

Email: MHgrants@wellcome.ac.uk

\section{Master's Fellowships in Public Health and Tropical Medicine \\ Subjects: Biomedical science.}

Purpose: This scheme strengthens scientific research capacity in low- and middle-income countries, by providing support for junior researchers to gain research experience and high-quality research training at Master's degree level. Research projects should be aimed at understanding and controlling diseases (either human or animal) of relevance to local, national or global health. This can include laboratory based molecular analysis of field or clinical samples, but projects focused solely on studies in vitro or using animal models will not normally be considered under this scheme. 
Eligibility: You should be: (1) A national or legal resident of a lowand middle-income country, and hold a first degree in subject relevant to tropical medicine or public health (clinical or non-clinical). (2) At an early stage in your career, with limited research experience, but have a demonstrated interest in or aptitude for research.

Level of Study: Postgraduate, Postdoctorate, Research

Type: Fellowship

Value: This fellowship normally provides up to 30 months' support. A period of 12 months should normally be dedicated to undertaking a taught Master's course at a recognized centre of excellence, combined with up to 18 months to undertake a research project. While undertaking a Master's course, fellows will receive a stipend in accordance with the cost of living in the country in which he/she will be studying; travel costs and support for approved tuition fees. Master's training by distance learning is acceptable. Master's course fees will be paid according to the rate charged by the training institution

Application Procedure: A completed application form [Word $1.58 \mathrm{MB}]$ should be submitted by the sponsor by the published deadline. The form should be emailed to phatic@wellcome.ac.uk. The application should include details of your sponsor's track record in training and a list of their other students at the institution. It must be supported by the head of the institution where the research will be based, and a career plan for the proposed candidate must be included.

Closing Date: March 2nd (for applications submissions) Funding: Trusts

Additional Information: For complete details go to address www.wellcome.ac.uk/Funding/Biomedical-science/Funding-schemes/ Fellowships/Public-health-and-tropical-medicine/wtd025881.htm.

\section{For further information contact:}

Tel: 02076115757

Email: sciencegrants@wellcome.ac.uk

\section{Medical History and Humanities Travel Grants}

Subjects: Medical history and humanities.

Purpose: Travel grants fund short-term visits by scholars

based outside the UK or the Republic of Ireland to one of these countries.

Eligibility: You must be based outside the UK or the Republic of Ireland and be applying to visit one of these countries. Visits under this scheme may be to consult libraries or archives and to exchange views or work with colleagues who have similar research interests. Study or lecture tours, meetings of a professional or vocational nature, workshops, symposia and international congresses are normally excluded. Experienced researchers need not be in academic life but will normally be expected to hold a doctorate or clinical qualification and have established a research interest in the medical humanities. Level of Study: Research

Type: Grant

Value: The maximum award under this scheme is $£ 1,500$ (although a slightly higher limit may apply in the case of researchers from certain developing countries)

Frequency: Available throughout the year

Application Procedure: Hard copy of the application form including signatures should be sent to the Trust's postal address, marked for the attention of Grants Management-History of Medicine.

Closing Date: Applications may be submitted at any time during the year

Funding: Trusts

\section{Pathfinder Awards}

Purpose: This scheme, offering pilot funding to catalyse innovative early-stage applied research and development projects in areas of unmet medical need, has been expanded. It now funds discrete projects from applicants in the UK and Republic of Ireland as well as partnerships between academia and industry based anywhere in the world.

Eligibility: Applications are welcome from academic and commercial organizations based in the UK or the Republic of Ireland. Applications from organizations and companies overseas will only be considered when applying in partnership. Check website for complete details.

Level of Study: Research

Type: Grant
Value: The average award amount is envisaged to be in the region of $£ 100,000$, but up to $£ 350,000$ will be considered in exceptional circumstances

Length of Study: 18 months

Frequency: Dependent on funds available, 4 times a year Application Procedure: You should contact us to confirm that your proposed application (and partnership, if appropriate), is eligible before submitting a full application form. After confirming that your application is eligible, you should complete the full application form (see 'Forms and guidance') and send it to innovations@wellcome. ac.uk before the deadline.

Closing Date: February (There will be four deadlines a year, subject to available budget.)

Funding: Trusts

For further information contact:

Email: innovations@wellcome.ac.uk

Website: www.wellcome.ac.uk/Funding/Innovations/Awards/

Pathfinder-Awards/index.htm

\section{People Awards and Society Awards}

Subjects: Project activities and outputs may include: workshops, events, debates and discussions; exhibitions and museum outreach; films, games, websites and cross-platform projects; performance or theatre projects involving existing work or work that may be more illustrative than artistic; deliberative or opinion-gathering projects; creation of teaching materials; projects that use the collections of the Wellcome Library and Wellcome Collection at the Science Museum. Purpose: People Awards and Society Awards are two related schemes supporting projects that encourage the public to explore biomedical science, its impact on society and culture, its historical roots or the ethical questions that it raises.

Eligibility: The scheme is open to a wide range of people, including mediators and practitioners of science communication; science centre/museum staff; artists; educators; health professionals; and academics in bioscience, social science, bioethics and history. Applicants are encouraged to apply through an organization rather than as individuals. If this is not possible, individuals can apply but they must demonstrate a strong track record in the area of their application. Applications will also be accepted from commercial companies who would not otherwise be able to undertake the proposed work and where outputs would not be considered for commercial funding. Organizations might include: museums and other cultural attractions; arts agencies; production companies; broadcast media; schools; local education authorities; universities and colleges; youth clubs; community groups; research institutes; the NHS; and science centres. Partnership projects (between different people and organizations, e.g. scientists and ethicists, educators and artists) are welcomed. If this is the first time an organization is applying to the Wellcome Trust an eligibility assessment will be carried out. For this assessment, the following documentation from the applying organization should be submitted: articles of association; audited accounts from the previous year; details of similar projects/grant funding received; confirmation that no funding has been received or is scheduled to be received from any tobacco company; standard health education and promotion projects, or projects dealing purely with nonbiomedical sciences, are not eligible.

Level of Study: Research

Type: Award

Value: Applicants can apply for up to $£ 40,000$ for projects lasting a maximum of 3 years

Frequency: Biannual

Application Procedure: You should complete and submit an application form by the published deadline.

Closing Date: January 27th, April 26th, July 26th and October 25th Funding: Trusts

Additional Information: Applicants must be based in the UK or the Republic of Ireland and the activity must take place in the UK or the Republic of Ireland.

\section{Postdoctoral Research Training Fellowships for Clinicians \\ Subjects: Biomedical science.}

Purpose: This is a flexible fellowship scheme to enable individuals to engage with areas of research that are new to them. It is for 
candidates who either undertook a PhD early in their career and now wish to refresh their research skills, or have recently completed a successful $\mathrm{PhD}$ and wish to explore a new research field or environment, to gain the skills that will help them answer their longerterm research vision.

Eligibility: The scheme may be suitable for clinicians who: are due to complete their higher degree or are no more than 2 years from the date of their PhD viva by the full application deadline; graduated with a $\mathrm{MB} / \mathrm{PhD}$ qualification or have achieved a high-quality $\mathrm{PhD}$ in a relevant subject, either during or prior to commencing their initial medical, veterinary or dental degree.

Level of Study: Research, Postgraduate

Type: Fellowship

Value: Awards are for 2-4 years, depending on whether or not you are planning to reintegrate into your clinical training programme. The total cost of a Fellowship would typically range from $£ 250,000$ to $£ 400,000$ Frequency: Annual

Application Procedure: A preliminary application form [Word 119kB] should be completed and submitted at any time before the published deadline. It should be sent electronically (as a Word document) to Dr Lucy Bradshaw (see website for contact details). If your preliminary application is successful, you will be invited to submit a full application. This will be reviewed and if successful you will be shortlisted for interview.

Closing Date: May 18th $(5 \mathrm{pm})$ for preliminary application; July 13th (5pm) for full application deadline; and November 19-20th (CIC) and November 25-27th (PHATIC) for shortlisted candidate interviews

Funding: Trusts

Additional Information: For more details see www.wellcome.ac.uk/ Funding/Biomedical-science/Funding-schemes/Fellowships/Clinicalfellowships/wtp052588.htm.

For further information contact:

Tel: 4402076115757

Email: sciencegrants@wellcome.ac.uk

Website: www.wellcome.ac.uk

\section{Principal Research Fellowships}

Subjects: Biomedical science.

Purpose: This is the most prestigious of our personal awards and provides long-term support for researchers of international standing. Successful candidates will have an established track record in research at the highest level.

Eligibility: You should have an established track record in research at the highest level. This award is particularly suitable for exceptional senior research scientists currently based overseas who wish to work in the UK or Republic of Ireland.

Level of Study: Postgraduate, Research

Type: Fellowship

Value: Awards are for 7 years in the first instance, and provide both a personal salary and research programme funding in full. After the first period of award, the fellowship will be subject to a competitive

scientific review, which will subsequently occur on a rolling basis every 5 years

Length of Study: 7 years

Frequency: Ongoing

Application Procedure: If you intend to apply you should contact us with a full curriculum vitae, preferably 18 months in advance of the desired award date. You may not apply for more than one Wellcome Trust fellowship scheme at any one time.

Closing Date: Applicants can express interest at any time. Interview usually held in June and December

Funding: Trusts

\section{For further information contact:}

Tel: 02076115757

Email: sciencegrants@wellcome.ac.uk

\section{Programme Grants}

Subjects: Medical history and humanities.

Purpose: Programme grants provide support for extensive or longterm research

Eligibility: Applicants should normally hold an established post in a university or institution in the UK or Republic of Ireland, and should have a good track record of research.
Level of Study: Research

Type: Grant

Value: A programme grant normally lasts for 5 years, and provides the salaries and associated costs for research assistants (if named, please include a full curriculum vitae); funds to cover travel, equipment and other items essential for research; a set amount for the applicant and any research assistants to attend conferences, seminars and other meetings of a scholarly nature. The level of support available depends on the needs of the programme, and the amount requested does not need to be above any particular threshold

Frequency: Thrice a year

Application Procedure: A preliminary application must be submitted, and should include: brief curriculum vitaes of the applicant(s), including full publication lists and the source of their salary/salaries (e.g. HEFC/NHS); an outline of the work (up to 5 pages) explaining the background and aims of the project, and the reason for requesting longer-term support; brief curriculum vitaes of any named research assistants; the approximate cost of the programme, broken down into salaries, equipment and project running costs; details of all current funding from the Trust and other bodies.

Closing Date: Preliminary applications should be sent in no later than the beginning of January, May or October

Funding: Trusts

\section{R\&D for Affordable Healthcare in India}

Subjects: Projects covering any aspect of technology development for healthcare will be considered, including diagnostics, therapeutics, vaccines, medical devices and regenerative medicine. Proposals drawing on the disciplines of the physical sciences, maths and engineering, as well as biomedicine, are equally encouraged. Purpose: The objective of this initiative is to fund translational research projects that will deliver safe and effective healthcare products for India, and potentially other markets, at affordable costs. A key feature of the scheme is that it encourages innovations that bring together researchers from both the public and private sectors to extend access to care to the greatest numbers of beneficiaries, without compromising on quality.

Eligibility: Awards will be agreed by Committee and governed by the terms and conditions, including Wellcome Trust Grant Conditions, funding terms for Affordable Healthcare. In addition there will be additional terms and conditions that will be negotiated under the funding agreement for the award with the applicant.

Level of Study: Research

Type: Award

Value: Awards will be made by way of funding agreements that will be negotiated on a case-by-case basis. The principles of the Wellcome Trust Grant Conditions will apply. The terms and conditions of funding will be discussed with applicants individually. Typically, the agreements will contain a provision for the appropriate sharing of benefits. The funds available will be ring-fenced for the specified programme of work. Neither working capital nor building or refurbishment expenditure will be provided. Funding will be released in tranches against the attainment of pre-agreed project milestones

Frequency: Twice a year

Application Procedure: In the first instance interested applicants should contact Dr Shirshendu Mukherjee to discuss their interest in funding via the Affordable Healthcare Initiative. Alternatively, applicants may complete a concept note and mail this directly to Dr Shirshendu Mukherjee.

Closing Date: January 31st

Funding: Trusts

\section{For further information contact:}

Email: s.mukherjee@wellcome.ac.uk

Contact: Dr Shirshendu Mukherjee, Senior Strategic Adviser

\section{Research Career Development Fellowships in Basic Biomedical Science}

Subjects: Biomedical Science.

Purpose: To provide support for outstanding postdoctoral scientists based in academic institutions in the UK and Republic of Ireland (Rol) Eligibility: You should have a relevant connection to the European Economic Area. You are expected to have science or veterinary qualifications and, at the preliminary application stage, should normally have between three and 6 years' research experience from the date of 
your doctoral degree (PhD viva). Due allowance will be given to those whose career has been affected for personal reasons. You must have made intellectual contributions to research that have been published in leading journals, and be able to demonstrate your potential to carry out independent research. The proposed research should fall within our normal funding remit. Resubmissions are not normally encouraged. If your application has been unsuccessful, please contact the Office for advice. You must have an eligible sponsoring host institution in the UK or Republic of Ireland (Rol) and an eligible sponsor who can guarantee space and resources for the tenure of any award.

Level of Study: Postdoctorate, Research

Type: Fellowship

Value: (1) A basic salary, as determined by the host institution, with an additional Wellcome Trust enhancement. (2) Research expenses, including research assistance if required (normally a graduate research assistant or technician; requests for additional research staff may be considered where fieldwork or clinical studies in a low- or middle-income country are proposed). (3) Overseas allowances where appropriate. (4) Travel and subsistence for scientifically justified visits of up to 1 year

Length of Study: 5 years

Frequency: Annual

Application Procedure: A preliminary application form [Word 89kB] should be completed and submitted by the published deadline. It should be sent electronically (as a Word document), with the requested accompanying information, to the appropriate funding stream at the Trust (see website). If successful, you will be invited to submit a full application.

Closing Date: Varies; refer to website www.wellcome.ac.uk/funding/ biomedical-science/funding-schemes/fellowships/basic-biomedicalfellowships/wtd004431.htm.

Funding: Trusts

\section{For further information contact:}

Tel: 02076115757

Email: sciencegrants@wellcome.ac.uk

\section{Research Expenses}

Subjects: Medical history and humanities.

Purpose: This scheme supports experienced researchers who wish to carry out a modest programme of study on a specific topic in the medical humanities within the UK and Republic of Ireland. This research does not necessarily have to be 'historically grounded'. It also provides modest assistance with research expenses for selffunded, part-time and full-time postgraduate students working for a doctorate on a history of medicine topic.

Eligibility: Applicants must be based in the UK or Republic of Ireland. Experienced researchers in an established academic post will normally be expected to have written some publications in an appropriate field. Experienced researchers not in an established academic post are expected to possess a doctorate or clinical qualification, and have established a research interest in the medical humanities. Self-funded, part-time and full-time students must be registered for a doctoral degree at a university or other institution of higher education in the UK or Republic of Ireland.

Level of Study: Research

Type: Grant

Value: Funding may be provided for a maximum of 2 years. The normal maximum award payable to postdoctoral scholars is $£ 5,000$. For self-funded doctoral students, the normal maximum award payable is $£ 3,000$

Frequency: Available throughout the year

Application Procedure: Hard copy of the application form including signatures should be sent to the Trust's postal address, marked for the attention of Grants Management - History of Medicine.

Closing Date: April 4th

Funding: Trusts

\section{Research Fellowships}

Subjects: Social and ethical aspects of biomedicine and healthcare. Purpose: Due to the multidisciplinary nature of research on the social and ethical aspects of biomedicine and healthcare, Research Fellowships may provide postdoctoral researchers with support to enable them to obtain research training, either in a new discipline or in a new aspect of their own field, e.g. a humanities scholar who wishes to be trained in social science. In such cases, the requested training must form a substantial component of the proposed research and should not normally be available via the standard funding routes, e.g. by learning new skills as a postdoctoral researcher on a project grant The requested training should also include methodologies and skills that are new to the applicant. Research training provision can include participation in taught courses, and periods spent in other research groups gaining practical, technical or other skills for introduction to the sponsor's or individual's own group.

Eligibility: You are eligible to apply if you are a postdoctoral scholar who is not in a tenured or otherwise long-term established post. Fellowships must be held at a UK, Irish or low- or middle-income country institution. You will also be expected to have been awarded your PhD before you are eligible to apply. Applications from candidates who are still awaiting their viva by the time of the full application will not normally be accepted.

Level of Study: Research

Type: Fellowship

Value: An award will not normally exceed $£ 250,000$, exclusive of any standard Wellcome Trust allowances. Fellowships provide a salary, plus appropriate employer's contributions. Essential research expenses, including travel and fieldwork, are available, as is a set amount for travel to conferences, seminars and other meetings of a scholarly nature

Length of Study: 3 years

Frequency: Biannual

Application Procedure: Preliminary applications should be made in writing, and include: a brief curriculum vitae and full publication list; details of research proposed (maximum of 1 page); a letter of support from the head of department in which you will be working; the approximate cost of the proposal, broken down into equipment and project running expenses.

Closing Date: 2016 deadlines: January round - January 22nd is closing date for preliminary applications and March 30th is closing date for full applications, The schedule for full applications received by March 30th closing date is as follows: May 2016 is shortlisting and July 2016: interviews; for July round - Dates are to be confirmed Funding: Trusts

Additional Information: The maximum duration of the awards is 3 years. The awards are full-time but can be tenable on a part-time basis if a case can be made that personal circumstances require this.

\section{For further information contact:}

Tel: 02076115757

Email: MHgrants@wellcome.ac.uk

\section{Research Resources in Medical History}

Subjects: Medical history and humanities-the next theme is Understanding the Brain.

Purpose: To provide funding for projects to catalogue and preserve significant collections of printed books and archives in the UK and Ireland. Applications must demonstrate the significance to the $\mathrm{MHH}$ research community and how collections fit within the themes identified in the Trust's Strategic Plan.

Eligibility: The scheme is open to any type of institution in the UK or Republic of Ireland, but not to individuals. Libraries, archives and repositories in all sectors are eligible. In exceptional circumstances, strategically important collections held in other countries might be eligible. Collaborative projects, which may be part-funded by other agencies or sources, will also be considered.

Level of Study: Research

Type: Grant

Value: Grants are normally between $£ 10,000$ and $£ 100,000$

Frequency: Thrice a year

Application Procedure: Preliminary applications should include the following: the completed application form; an explanation of how the collection contents fit within the current theme. Collections that address more than one theme can be considered (applicants should discuss their collections with Trust staff first for advice on the timing of their applications); a description of the size of the collection, type of material and physical condition; an estimate of the costs required and how the funds will be used, i.e. for preservation, cataloguing, digitization; brief curriculum vitaes of the principal applicants; any reports or information provided by initial scoping phases such as preservation needs assessments or preliminary sorting. 
Closing Date: June 7th (Preliminary application deadline); October 1st (Full application deadline)

Funding: Trusts

\section{Research Training Fellowships}

Subjects: Medical, dental, veterinary or clinical psychology.

Purpose: Provide support for medical, dental, veterinary and clinical psychology graduates who have little or no research training, but who wish to develop a long-term career in academic medicine.

Eligibility: The fellowship is open to individuals with a relevant connection to the European Economic Area (EEA) for fellowships to be held in a UK or Republic of Ireland institution. Non-U.K. candidates should contact the office for advice before submitting an application (1) Medical graduates must have passed the relevant exam for their specialty, e.g. MRCP, MRCS, MRCOphth/FRCOphth Part 1, MRCPsych, MRCOG Part 1, MRCPCH, FRCA Part 1. GPs are advised to contact the office to clarify their eligibility. (2) Dental candidates must have obtained MFD, MFDS, MGDS, MFGDP or equivalent. (3) Veterinary candidates should have a degree in veterinary medicine (e.g. BVSc, BVM\&S, BVMS, BVetMed, VetMB) and some experience in clinical practice. An intercalated degree is desirable, but not essential. (4) Clinical psychology candidates must have obtained a professional Doctorate-level qualification in Clinical Psychology accredited by the British Psychological Society before taking up the award. Candidates are advised to contact the office to clarify their eligibility. You are expected to undertake a high-quality research project that balances the provision of training with the opportunity to advance knowledge in a given area. A project based solely on a systematic review of a particular area is not suitable, unless it includes a significant element of methodological innovation. Level of Study: Postgraduate, Research

Type: Fellowship

Value: Fellowships are normally for 2-3 years. In exceptional cases a fellowship may be for up to 4 years for those who wish to undertake a relevant Master's training or diploma course. All training requests must be fully justified in the application. Fellowships provide research expenses (consumables, travel, and support to attend scientific meetings) and a fellow's salary, set according to age, experience and our policy on enhancement

Length of Study: 2-3 years

Frequency: Three times per year

Application Procedure: Application form is available from the website.

Closing Date: Varies; refer to the website www.wellcome.ac.uk/ Funding/Biomedical-science/Funding-schemes/Fellowships/Clinicalfellowships/wtd004435.htm.

Funding: Trusts

\section{For further information contact:}

Tel: 02076115757

Email: sciencegrants@wellcome.ac.uk

\section{Science Media Studentships}

Subjects: These studentships offer financial support for three PhDlevel biomedical scientists to undertake postgraduate qualifications at Imperial College London or the National Film and Television School (NFTS)

Purpose: We aim to increase the crossover between science and the media and to enable bright, articulate and motivated scientists to explore a career in the broadcast industry.

Eligibility: Applicants should be PhD-level biomedical scientists wishing to explore a career in the broadcast, games and film industries. Applicants must have a $\mathrm{PhD}$ or equivalent, some experience of science communication, and a demonstrable aptitude for working with TV, radio, film or games.

Level of Study: Postdoctorate, Research

Type: Studentship

Value: Awards will pay for tuition costs plus a grant to cover basic living expenses for the duration of the studentship

Frequency: Annual

Application Procedure: Application is through the Imperial College website.

Closing Date: February 26th

Funding: Trusts

\section{For further information contact:}

Tel: 02075948753

Email: liam.watson@imperial.ac.uk

Contact: Liam Watson, Science Communication Group Administ

\section{Seeding Drug Discovery}

Subjects: The aim is to develop drug-like, small molecules that will be the springboard for further research and development by the biotechnology and pharmaceutical industry in areas of unmet medical need.

Purpose: To facilitate early-stage small-molecule drug discovery. The awards help applicants with a potential drug target or new chemistry embark on a programme of compound discovery and/or lead optimization.

Level of Study: Research

Type: Award

Value: Early-stage drug discovery projects are able to apply for funding for up to 2 years to facilitate screening of chemical compounds to identify one or more lead series of molecules. Late-stage projects, where a lead compound has already been identified, are able to apply for funding for up to 4 years, to support lead optimization and preclinical development through to clinical trials

Frequency: Twice a year

Application Procedure: A preliminary application form should be completed and returned to Technology Transfer by the published deadline. Applications will be considered at one of the two Seeding Drug Discovery Committee meetings in each 12-month period. Successful applicants will be shortlisted and invited to complete a full application.

Closing Date: Varies; refer to the website www.wellcome.ac.uk/ Funding/Innovations/Awards/Seeding-Drug-Discovery/index.htm. Funding: Trusts

For further information contact:

Tel: 02076115757

Fax: 02076118857

Email: innovations@wellcome.ac.uk

\section{Senior and Intermediate Research Fellowship for International Students}

Subjects: Fellowship is awarded to support biomedical research that is relevant to human and animal welfare.

Purpose: The aim of the fellowship is to supports outstanding researchers of any nationality, either medically qualified or science graduates, who wish to pursue a research career in an academic institution in India.

Eligibility: Applicants of any nationality are eligible to apply for the fellowship. Applicants must be a basic science/veterinary researchers with $4-15$ years of post-PhD research experience. Applicants must be fluent in English.

Level of Study: Research

Type: Research

Value: The fellowship has the tenure of 5 years and provides: The Fellow's personal support, research expenses, including research assistance if required (normally funding for four research staff may be requested). The total award for a Senior Fellowship typically includes the costs requested by the applicant as well as the set contributions by the India Alliance. For further details, see costing policies. Costs requested by the applicant must be commensurate with their research proposal and should be fully justified in the full application. Inadequate justifications may result in costs being revised. Time permitted for non-research related activity during the fellowship is normally restricted to a maximum of 8 hours each week.

Study Establishment: Fellowship is awarded to support biomedical research that is relevant to human and animal welfare

Country of Study: India

No. of awards offered: Number of fellowships is not given Application Procedure: See the website.

Closing Date: January 15th

Additional Information: For more details please visit the website http://scholarship-positions.com/senior-intermediate-research-fellowship-for-international-students-india/2018/01/02/. 


\section{Senior Fellowships in Public Health and Tropical Medicine}

Subjects: Biomedical science.

Purpose: This scheme supports outstanding researchers from lowand middle-income countries to establish themselves as leading investigators at an academic institution in a low- and middle-income country location. This fellowship is the most senior of a series of career awards aimed at building sustainable capacity in areas of research that have the potential for increasing health benefits for people and their livestock in low- and middle-income countries. Research projects should be aimed at understanding and controlling diseases (either human or animal) of relevance to local, national or global health. Eligibility: Candidate must be a graduate in a subject relevant to public health or tropical medicine (for example; biomedical or social science, veterinary medicine, physics, chemistry or mathematics) with a PhD and at least 5 years' postdoctoral experience, or a medical graduate with a higher qualification equivalent to membership of the U.K. Royal College of Physicians (i.e. qualified to enter higher specialist training), or be recognized as a specialist within a relevant research area, and have at least 5 years' research experience.

Level of Study: Postgraduate, Research

Type: Fellowship

Value: A basic salary; research expenses (e.g. consumables, equipment, collaborative travel, research assistance, technical support), training costs where appropriate and justified; an inflation/ flexible funding allowance and support to attend scientific meetings; and contributions to costs of the project that are directly incurred by the overseas institution may also be provided

Length of Study: Up to 5 years

Frequency: Thrice a year

Application Procedure: You are required to complete and submit a preliminary application form [Word 236kB] by the published deadline. The form should be emailed to phatic@wellcome.ac.uk. Completed forms will normally be assessed within 1 month of the preliminary deadline. If your preliminary application meets the scheme's requirements, a full application will be invited.

Closing Date: Varies; refer to the website www.wellcome.ac.uk/ Funding/Biomedical-science/Funding-schemes/Fellowships/Publichealth-and-tropical-medicine/wtd025884.htm.

Funding: Trusts

Additional Information: Overseas allowances will be provided for periods of training or collaborative research spent outside the home institution country, where appropriate. Research-dedicated costs (excluding salary costs) should not exceed $£ 100,000$ per year.

\section{For further information contact:}

Tel: 02076115757

Email: sciencegrants@wellcome.ac.uk

\section{Senior Investigator Awards}

Subjects: Biomedical science.

Purpose: To support exceptional, world-class researchers, who hold an established academic position and have a compelling long-term vision for their research. We will support researchers who have an international track-record of significant achievement, who have demonstrated the originality and impact of their research, and who are leading their field.

Eligibility: If you are based in the UK, Republic of Ireland or a low- or middle-income country: you should have an established academic post at an eligible higher education or research institution. By this we mean you are employed on a permanent, open-ended or long-term rolling contract, salaried by your host institution. You are also eligible to apply if you have a written guarantee of an established academic post at your host institution, which you will take up by the start of the award. If you are uncertain as to whether your employment status meets the above eligibility criteria, please contact the Trust for advice (see 'Contacts'). If you are based in a low- or middle-income country in sub-Saharan Africa, South East Asia or South Asia (with the exception of India - see below) please note also that: you are eligible to apply if you fulfil the above eligibility criteria and are working within the Trust's broad science funding remit. If you are based in a low- or middleincome country other than in the territories mentioned above, please note that: you are eligible to apply only if you are a researcher carrying out research in the fields of public health and tropical medicine aimed at understanding and controlling human and animal diseases of local, national and global health importance. The Senior Investigator Award scheme is not available to researchers in India (please see guidance on schemes offered by the Wellcome Trust/Department of Biotechnology India Alliance), or in countries where we currently offer International Senior Research Fellowships.

Level of Study: Research

Type: Award

Value: Awards may be small or large, typically up to $£ 3,000,000$, and lasting up to 7 years. Please note that awards may not necessarily be made at the upper end of this range, and we expect costs to be suited to and justified by the proposed research. Covers cost of research expenses, including research assistance, animals, equipment and funding for collaborative activity, travel and subsistence for scientifically justified visits, overseas allowances where appropriate. The award does not include your salary costs

Frequency: Annual

Application Procedure: Stage 1 is curriculum vitae details check, stage 2 is main application, stage 3 is scientific review and shortlisting, stage 4 is external peer review, and stage 5 is interview.

Closing Date: Varies; refer to the website www.wellcome.ac.uk/ Funding/Biomedical-science/Funding-schemes/investigator-awards/ wtx059285.htm

Funding: Trusts

Additional Information: Please apply via the eGrants facility on the institution website.

\section{Senior Research Fellowships in Basic Biomedical Science}

Subjects: Biomedical science.

Purpose: To provide support for outstanding postdoctoral scientists based in academic institutions in the UK and Republic of Ireland (Rol) Eligibility: The fellowship is open to individuals with a relevant connection to the EEA. You should have between 5 and normally 10 years' research experience (from the date of your viva to the date of your preliminary application) at postdoctoral level, or veterinary equivalent, and have a substantial record of publications in your chosen area of research in leading international journals. Candidates that do not hold an established post may apply to remain in their current laboratory, to return to one where they have worked before or to move to a new laboratory in the UK or Republic of Ireland.

Candidates that hold an established post are not eligible to apply for a fellowship to be held at their current employing institution. However, we are willing to consider a preliminary application where a candidate wishes to move institution and is able to make an appropriate justification for the move. The Trust does not normally accept resubmissions of full applications for its fellowships. Please contact the Office for further advice. You must have an eligible sponsor and host institution in the UK or Republic of Ireland who can guarantee space and resources for the tenure of the award.

Level of Study: Research, Postdoctorate

Type: Fellowship

Value: The fellowship is for 5 years in the first instance, and provides a basic salary, as determined by the host institution (normally up to $£ 55,000$ per year) with an additional Trust supplement of $£ 12,500$ per year; the essential costs of the research programme (e.g. consumables, equipment, research assistance, overseas allowances, collaborative travel and subsistence); an inflation and Flexible Funding Allowance; and support to attend scientific meetings

\section{Frequency: Annual}

Application Procedure: A preliminary application form [Word 223kB] should be completed and submitted electronically (as a Word document) to the relevant funding stream (see website) no later than the published deadline. Full application forms will usually be sent to shortlisted candidates within 1 month of the preliminary deadline. In the full application, if invited, the host institution will be required to confirm that it will support a successful renewal of the fellowship under the shared funding arrangement for the full period of any renewal.

Closing Date: Varies; refer to the website www.wellcome.ac.uk/ funding/biomedical-science/funding-schemes/fellowships/basic-biomedical-fellowships/wtd004442.htm.

Funding: Trusts

\section{For further information contact:}

Tel: 02076115757

Email: sciencegrants@wellcome.ac.uk 


\section{Senior Research Fellowships in Clinical Science}

Subjects: Biomedical science.

Purpose: This scheme provides support for clinical investigators to further develop their research potential and to establish themselves as leading investigators in clinical academic medicine.

Eligibility: You must have a relevant connection to the EEA. If you are a non-U.K. candidate, please contact the Office for advice before submitting a preliminary application. You should be a clinical scientis with a medical, dental, veterinary or clinical psychology qualification and will normally have no more than 15 years' clinical and research experience from the date of your first medical, dental, veterinary or British Psychological Society-accredited psychology qualification. (Due allowance will be given to those whose career has been affected by a late start or interruption for personal/family reasons.) Successful candidates will have made significant progress towards establishing themselves as independent clinical investigators. A research degree (PhD/MD), together with evidence of advanced (postdoctoral) research training (typically at least $3-5$ years), is expected. They will have published consistently in their chosen area of research, placing substantive papers in leading journals. Candidates will not normally hold a tenured academic post in a university in the UK or Republic of Ireland, or a consultant post in the NHS.

Level of Study: Postgraduate, Research

Type: Fellowship

Value: The fellowship is for 5 years in the first instance, and provides: a basic salary, as determined by the host institution; research expenses; an inflation allowance and support to attend scientific meetings; provision for public engagement cost

Frequency: Annual

Application Procedure: A preliminary application form [Word 232kB] should be completed and submitted by the published deadline. It should be sent electronically (as a Word document), with the requested accompanying information, to the appropriate funding stream at the Trust (see website). Incomplete or incorrectly completed forms will not be accepted. Faxed applications will not be accepted. Please do not send any additional material. You will be notified in writing of your success, or otherwise, in reaching the next round of the competition. In some instances, we may recommend that candidates apply for an Intermediate Clinical Fellowship.

Closing Date: Varies; refer to the website www.wellcome.ac.uk/ funding/biomedical-science/funding-schemes/fellowships/clinicalfellowships/wtd004445.htm.

Funding: Trusts

\section{For further information contact:}

Tel: 02076115757

Email: sciencegrants@wellcome.ac.uk

\section{Short-term Research Leave Awards for Clinicians and \\ Scientists}

Subjects: Medical history and humanities.

Purpose: This scheme enables clinicians, scientists and other healthcare professionals to undertake up to 6 months (FTE) of research at a centre or department with academic expertise in medical humanities, to explore the wider determinants and contexts of their own medical and scientific work.

Eligibility: You should be a scientist, clinician or healthcare professional holding an established post to which you would return on completion of the award. You must be resident in the UK or Republic of Ireland. You should have a record of publication in medical or scientific journals.

Level of Study: Research

Type: Award

Value: We will provide the salary of a locum or replacement lecturer for the duration of the award, and a set amount for travel to conferences

Length of Study: Up to 6 months

Frequency: Thrice times a year

Application Procedure: You should submit a preliminary application in writing, including: a brief curriculum vitae, a full publication list and confirmation that your personal support is from the Higher Education Funding Council; details of the research proposed (maximum one page); details of hours spent on teaching and administration; the approximate cost of the proposal, broken down into staff salaries, equipment and running expenses.
Closing Date: January 23rd (preliminary applications for January round); July (preliminary applications for July round). For further detail check website www.wellcome.ac.uk/Funding/Medical-humanities/ funding-schemes/personal-awards/wtd003761.htm.

Funding: Trusts

For further information contact:

Tel: 02076115757

Email: MHgrants@wellcome.ac.uk

\section{Sir Henry Wellcome Postdoctoral Fellowships}

Subjects: Biomedical science.

Purpose: To provide a unique opportunity for the most promising newly qualified postdoctoral researchers to make an early start in developing their independent research careers, working in the best laboratories in the UK and overseas.

Eligibility: These awards are open to individuals with a relevant connection to the European Economic Area. You must be in the final year of your PhD studies or have no more than 1 year of postdoctoral research experience from the date of your PhD viva to the full application submission deadline (e.g. if the full deadline is in February, your viva should not have occurred prior to last February). Time spent outside the research environment will be taken into consideration. You must have an eligible sponsoring institution in the UK or Republic of Ireland that will administer the fellowship for the full duration of the award.

Level of Study: Postdoctorate, Research

Type: Fellowships

Value: 4 year full-time fellowship. Provides an award of $£ 250,000$

Length of Study: 4 years

Frequency: Annual

Application Procedure: You should complete and submit a preliminary application form by the published deadline. It should be sent electronically (as a Word document), with the requested accompanying information, to the relevant funding stream at the Trust. Your preliminary application will be assessed within 4 weeks of the submission deadline. If successful, you will be invited to submit a full application. Your full application will be peer reviewed by the relevant Funding Committee and, if successful, you will be shortlisted for interview.

Closing Date: Varies; refer to the website www.wellcome.ac.uk/ Funding/Biomedical-science/Funding-schemes/Fellowships/Basicbiomedical-fellowships/wtx033549.htm.

Funding: Trusts

For further information contact:

Tel: 02076115757

Email: sciencegrants@wellcome.ac.uk

\section{Society Awards}

Subjects: Our aim is to encourage people of all ages and walks of life to learn about these developments and have an opportunity to consider, question and debate the implications and issues arising from such work. By inspiring, informing and involving whole communities, Society Awards enable people to consider and discuss issues that affect them, those close to them and the world in which they live. Projects should aim to achieve at least one of the following: stimulate interest, excitement and debate about biomedical science through various methods; examine the social, cultural, historical and ethical impact of biomedical science; encourage new ways of thinking about biomedical science.

Purpose: Society Awards are for ambitious and creative projects that engage people with developments in biomedical science on a regional or national scale.

Eligibility: The scheme is open to anyone with a good idea for engaging people with developments in biomedical science. This might include: mediators and practitioners of science communication; science centre/museum staff; artists; educators; health professionals; and academics in bioscience, social science, bioethics and history. Grants will normally be awarded through organizations, but individuals can apply. Organizations might include: venues attracting large audiences (e.g. museums, cultural attractions or nature attractions); arts agencies; production companies; schools; local education authorities; universities; youth clubs; community groups; research institutes; the NHS; and science centres. Partnership projects 
(between different people and organizations, e.g. scientists and ethicists, educators and artists) are welcomed. Please note that standard health education and promotion projects, or projects dealing purely with non-biomedical sciences, are not eligible. Large broadcast media projects are not eligible for consideration through the Society Awards. These projects can be considered through our Broadcast Strategy and the Large Broadcast Awards. Smaller broadcast media projects are eligible for funding either through the People Awards (for production costs) or the Broadcast Development Awards (for development costs)

Level of Study: Research

Type: Award

Value: Society Awards are for amounts over $£ 30,000$, for a maximum of 3 years

Frequency: Annual

Application Procedure: Please contact the Society Awards office well in advance of the preliminary deadline to discuss a potential application. You must complete and submit a preliminary application form by the published deadline.

Closing Date: March 28th

Funding: Trusts

Additional Information: Applicants must be based in the UK or the Republic of Ireland and the activity must take place in the UK or the Republic of Ireland.

\section{Strategic Awards in Biomedical Science}

\section{Subjects: Biomedical science.}

Purpose: Strategic Awards provide flexible forms of support to excellent research groups with outstanding track records in their field. Eligibility: Applications will be considered from principal applicants who meet our eligibility criteria and are recognized international leaders in their field.

Level of Study: Research

Type: Award

Value: It provides equipment, support staff, consumables, training programmes, networking, biological, clinical or epidemiological research resources. Limited capital building or refurbishment essential to the programme can also be requested

Length of Study: Awards are normally for 5 years

Frequency: Ongoing

Application Procedure: You (prospective applicant) are required to submit a preliminary application, which should include the following information: (1) your track record, you must complete the curriculum vitae pages [Word 112kB] (these are questions 14 and 15 from the standard project grant application form); (2) high-level aims and objectives, and how the proposal addresses the strategic challenges in the Wellcome Trust's Strategic Plan for 2010-2020 (maximum of two pages); (3) key targets, milestones and management structures, if appropriate (maximum of two pages); (4) duration of support requested and outline costings broken down into main headings (e.g. staff, equipment); (5) a statement from the head of the institution, indicating how the proposal fits within the context of the institution's strategic vision and what financial commitment the institution will make to the group if the application is successful. If your preliminary application is successful, you will be invited to submit a full application. The relevant form will be provided at this time.

Closing Date: Refer website

Funding: Trusts

For further information contact:

Tel: 02076115757

Email: sciencegrants@wellcome.ac.uk

\section{Strategic Translation Awards}

Subjects: For Strategic Translation Awards the Trust will normally actively participate in the stewardship of the project and lead on intellectual property management and exploitation. A wide range of biomedical developments can be considered, including therapeutics, vaccines, diagnostics, enabling technologies (including research tools), medical devices and regenerative medicine.

Purpose: Strategic Translation Awards support research projects that are viewed as strategically important to the Wellcome Trust's mission. Technology Transfer at the Wellcome Trust proactively seeks applications from scientists who wish to work in partnership with the Trust to achieve commercialization of their inventions. Compared with the Translation Awards, the Trust is more proactively engaged in project management, working alongside the institution or company involved. Strategic projects are exceptional projects that-due to the combination of potential high impact, risk, scale or complexity-warrant strategic status to provide a high level of momentum for the project. Eligibility: Applications are welcome from research centres (non profit making). Businesses who undertake medical research can also apply. Projects that will be viewed as eligible will be addressing unmet needs in healthcare or in applied medical research.

Level of Study: Research, Postgraduate

Type: Award

Value: The important criterion is to develop the innovation to the point at which it can be adopted by another party. Awards will normally be for periods of 2-3 years, but can be longer in exceptional cases. Providing it is adequately justified, modest equipment purchase and maintenance costs may be included in an application. Building or refurbishment expenditure will not normally be considered. Applications may not include requests for academic institutional overheads Length of Study: 2-3 years, but can be longer in exceptional cases Application Procedure: Prospective applicants should first contact Technology Transfer staff at the Wellcome Trust to discuss their proposal. You will then be asked to submit a preliminary application, which will be considered for its strategic potential and the likely impact of the project downstream. If successful, you will be invited to submit a full application. The further progression of any strategic proposal will be dependent upon successful due diligence by the Wellcome Trust, and only those applications that are competitive will be taken forward to a Technology Transfer Strategy Panel decision. All funding decisions are made by the Strategy Panel.

Closing Date: The deadlines are as follows: April 15th (concept note); June 13th (preliminary)

Funding: Trusts

Support for Conferences, Symposia and Seminar Series Subjects: Medical history and humanities.

Purpose: This scheme provides institutions with financial support for conferences (or a session within a conference), symposia, seminar series, etc

Eligibility: You should be based at an eligible institution in the UK or Republic of Ireland. Awards are not normally made to individuals, so please name the institution to which the award should be made.

Grants are not available for symposia held in association with established organizations with permanent staff, or to support large international meetings or learned societies overseas.

Type: Grant

Value: The Trust will consider making small contributions in the region of $£ 1,000-10,000$

Frequency: Available throughout the year

Application Procedure: An application form needs to be completed. Closing Date: Applications may be submitted at any time throughout the year Funding: Trusts

\section{Training Fellowships in Public Health and Tropical Medicine}

Subjects: Biomedical science.

Purpose: This scheme provides researchers from low- and middleincome countries-who are at an early stage in the establishment of their research careers-with opportunities for research experience and high-quality research training in public health and tropical medicine. Research projects should be aimed at understanding and controlling diseases (either human or animal) of relevance to local, national or global health. This can include laboratory-based molecular analysis of field or clinical samples, but projects focused solely on studies in vitro or using animal models will not normally be considered under this scheme.

Eligibility: Applications are only accepted in the Public Health and Tropical Medicine Interview Committee remit. This covers research on infectious and non-communicable diseases within the fields of public health and tropical medicine that is aimed at understanding and controlling diseases (either human or animal) of relevance to local, national or global health. You must be a national or legal resident of a low- and middle-income country and should be either: (1) a graduate in a subject relevant to public health or tropical medicine (e.g. biomedical or social science, veterinary medicine, physics, chemistry 
or mathematics) with a $\mathrm{PhD}$ and no more than 3 years' postdoctoral experience, or (2) a medical graduate with a higher qualification equivalent to membership of the UK Royal Colleges of Physicians (i.e. qualified to enter higher specialist training) and some initial research experience. Applicants may also apply if they do not have a PhD, but have a clinical, basic or Master's degree and some initial research experience, with the expectation that they will register for a $\mathrm{PhD}$.

Level of Study: Postgraduate, Research

Type: Fellowship

Value: It provides support that includes a basic salary for the fellow, research expenses (e.g. consumables, equipment, collaborative travel, research assistance, technical support) training costs where appropriate and justified, an inflation/flexible funding allowance and support to attend scientific meetings, and contributions to costs of the project that are directly incurred by the overseas institution may also be provided

Length of Study: 3 years

Frequency: Thrice a year

Application Procedure: You are required to complete and submit a preliminary application form (Word $236 \mathrm{kB}$ ) by the published deadline. The form should be emailed to phatic@wellcome.ac.uk. Completed forms will normally be assessed within 1 month of the preliminary deadline. If the preliminary application meets the scheme's requirements, you will be invited to submit a full application.

Closing Date: Varies; refer to the website www.wellcome.ac.uk/ Funding/Biomedical-science/Funding-schemes/Fellowships/Publichealth-and-tropical-medicine/wtd025882.htm

Funding: Trusts

\section{For further information contact:}

Tel: 02076115757

Email: sciencegrants@wellcome.ac.uk

\section{Translation Fund}

Subjects: Projects covering any aspect of technology development from a range of disciplines-including physical, computational and life sciences-will be considered. Projects must address an unmet need in healthcare or in applied medical research, offer a potential new solution, and have a realistic expectation that the innovation will be developed further by the market.

Purpose: Translation Awards are response-mode funding designed to bridge the funding gap in the commercialisation of new technologies in the biomedical area.

Eligibility: Projects must address an unmet need in healthcare or in applied medical research, offer a potential new solution, and have a realistic expectation that the innovation will be developed further by the market. Institutions: eligible institutions are not-for-profit research institutions, including those funded by the Medical Research Council, Cancer Research UK, and Biotechnology and Biological Sciences Research Council, in the UK. Institutions are normally required to sign up to a short funding agreement and the Grant Conditions.

Companies: we are able to use our charitable monies to fund commercial companies to meet our charitable objectives through programme-related investment (PRI). For further details please refer to our policy on PRI. Companies will normally be expected to sign up to specific terms relating to the scheme. Overseas organizations: U.K. organizations may contract or collaborate with overseas organizations. Although overseas organizations are not eligible for Translation Awards, some proposals may be invited for consideration as a Strategic Translation Award (including Seeding Drug Discovery). Overseas organizations should contact Technology Transfer staff about their proposed project in the first instance. Principal applicants and coapplicants: applicants should normally hold a position of responsibility within the eligible organization and be able to sign up to or comply with the conditions or terms of an award. In addition, postdoctoral research assistants-whether seeking their own salary as part of the grant proposal, funded by the Wellcome Trust on another grant, or funded by another agency-are eligible for coapplicant status if they make a significant contribution to a research proposal and have agreement from their funding agency. Other eligibility information: Disciplines outside biomedicine - researchers from disciplines outside biomedicine can apply providing the application of research is designed to facilitate or meet a need in healthcare. For example, the application of physics, chemistry, computing, engineering and materials science to the development of medical products is entirely appropriate. Healthcare need in an area that is not commercially attractive. We are committed to the translation of research into practical healthcare benefits across the full spectrum of disease. Disease areas neglected by industry because of the lack of a return on investment pose a particular problem, but imaginative ways forward can sometimes be developed (e.g. public-private partnerships such as the Medicines for Malaria Venture). Intellectual property rights (IPR)/ publications - if there are any restrictions on IPR or publications arising from your research, you must provide a written statement that details them. Restrictions on intellectual property may affect your eligibility to apply to the Trust. Please refer to our Grant Conditions. Level of Study: Research

Type: Award

Value: The important criterion is to develop the innovation to the point at which it can be adopted by another party. Providing it is adequately justified, modest equipment purchase and maintenance costs may be included in a Translation Award application. Building or refurbishment expenditure will not normally be considered. Applications may not include requests for academic institutional overheads. If you hold a tenured university post, you may not re-charge your salary (in full or part) to a Translation Award

Frequency: Four times a year

Application Procedure: A preliminary application form must be completed and sent to Technology Transfer by the published deadline. Preliminary applications are subject to a triage for shortlisting for the full application stage. Applications will be considered by the Technology Transfer Challenge Committee (TTCC), which meets twice a year. Full applications will be invited following the triage meeting. Shortlisted applicants will be invited to submit a full application and will be subject to international peer review and due diligence. Applicants will be expected to make a presentation on their proposal to the TTCC. Unless otherwise advised, this will be at the next scheduled meeting of the TTCC.

Closing Date: Concept note deadline: April 15th; Preliminary deadline: June 12th

Funding: Trusts

\section{For further information contact:}

Tel: 02076115757

Fax: 02076118857

Email: innovations@wellcome.ac.uk

\section{Translational Medicine and Therapeutics Programmes}

Subjects: Biomedical science.

Purpose: This flagship scheme established four high-quality integrated research training programmes for clinicians in translational medicine and therapeutics. The programmes have been developed around a unique partnership between academic and industrial partners. Support for the programmes has been provided to the host institutions by GlaxoSmithKline, Wyeth Research, Roche, AstraZeneca, Sanofi-Aventis, Sirtris Pharmaceuticals and PTC Therapeutics. Eligibility: You should have demonstrated the potential to pursue a career as an academic clinician. It is anticipated that many applicants will have already commenced their specialist training, but this is not essential.

Level of Study: Postgraduate, Research

Value: Includes a clinical salary, $\mathrm{PhD}$ registration fees at U.K./EU rate, research expenses, contribution towards travel, and a contribution towards training costs

Length of Study: Support varies

Frequency: Annual

No. of awards offered: Four programmes have been established, based in centres of excellence throughout the UK.

Application Procedure: If you are interested in applying you should contact the relevant programme. Please see website for details.

Closing Date: October

Funding: Trusts

For further information contact:

Email: j.williams@wellcome.ac.uk

\section{University Awards}

Subjects: Medical history and humanities.

Purpose: This scheme allows universities to attract outstanding research staff by providing support for up to 5 years, after which time 
the award holder takes up a guaranteed permanent post in the university. A monograph and other substantial publications are expected to result from an award, so teaching and other non-research commitments are expected to be minimal during the period of full Wellcome Trust support.

Eligibility: You must be nominated by your prospective head of department and have an undertaking from the head of the institution, vice-chancellor, principal or dean that your personal support will be taken over by the institution at the end of the award. Support is normally available only at lecturer level, although in exceptional cases awards to senior-lecturer level may be possible.

Level of Study: Research

Type: Award

Value: Up to 5 years' support is available, providing your full salary for 3 years, 50 per cent in the fourth year and 25 per cent in the fifth year. Travel expenses to attend meetings are provided for 5 years, but research expenses are provided for the first 3 years of the award only Frequency: Thrice a year

Application Procedure: Initial enquiries about the scheme may be made by you (the potential candidate) or a department in an institution. These enquiries should be followed by a preliminary application from you by email or post including an explicit statement from the head of the institution, vice-chancellor or dean demonstrating the institution's commitment to the history of medicine field, and a statement confirming that the institution will provide 50 per cent salary costs in year four, 75 per cent in year 5 and full salary thereafter; curriculum vitae and full publication list; an outline of no more than two pages of the proposed project; a letter of support from the head of department, including a statement on your expected teaching/ administrative load for the 5-year period (this can be sent by separate cover); the approximate cost of the proposal, broken down into your salary, equipment and project running costs.

Closing Date: January 22nd (closing date for preliminary applications); March 30th closing date for full applications; The schedule for full applications received by March 30th closing date is as follows: May 2016 is shortlisting and July 2016 is interview. July round - Dates to be announced shortly.

Funding: Trusts

For further information contact:

Tel: 02076115757

Email: MHgrants@wellcome.ac.uk

\section{Value in People Awards}

Subjects: Biomedical science.

Purpose: These awards help universities with the recruitment, career progression and retention of key academic and research staff. Awards are provided to the top 30 Trust-funded universities.

Eligibility: See a list of universities currently in receipt of funding on website.

Level of Study: Professional development

Type: Award

Value: The amount of funding to support VIP awards is $£ 200,000$

Frequency: Various

Application Procedure: Awards are administered by the recipient universities.

Closing Date: Deadline for applications - November 5th, February 19th, June 3rd and Decision expected - December 7th, March 25th, July 8th

Funding: Commercial, corporation, foundation, government, individuals, international office, private, trusts

Additional Information: Refer websit for more details.

\section{Wellcome Trust and Howard Hughes Medical Institute \\ Exchange Programme}

Subjects: Biomedical science.

Purpose: The Wellcome Trust and Howard Hughes Medical Institute (HHMI) Exchange Programme promotes international collaborations among scientists funded by the Trust and HHMI. The programme provides training and career opportunities for members of Trustfunded teams to work with eligible HHMI laboratories.

Eligibility: In partnership with a HHMI investigator, or a group leader or fellow at the Janelia Farm Research Campus, the Exchange Programme is open to the following Trust grantholders: (1) Senior Research Fellows in Basic Biomedical Science; (2) Senior Research
Fellows in Clinical Science; (3) Principal Research Fellows;

(4) Programme grantholders in a UK Wellcome Trust Centre;

(5) Investigators at the Wellcome Trust Sanger Institute. HMMI investigators and group leaders/fellows at the Janelia Farm Research Campus wishing to apply for an award should contact $\mathrm{HHMI}$ directly.

Level of Study: Research

Value: Funding is provided for between 3 and 12 months for a Trustfunded postdoctoral researcher to visit the laboratory of an $\mathrm{HHMI}$ investigator or group leader/fellow in the Janelia Farm Research Campus. Costs will be provided for the postdoctoral researcher's return flight to the USA and subsistence (an allowance of $£ 1,500$ for each month of the proposed visit). Funding will be provided as a supplement to the award on which the postdoctoral researcher is supported and he/she should have salary support available on that award for the duration of the proposed exchange

Frequency: Annual

No. of awards offered: 1

Application Procedure: Trust-funded applicants should complete an application form [Word $90 \mathrm{kB}$ ] and return a hard copy to the relevant Scientific Programme Officer or funding stream (see website).

Closing Date: Applications can be made at any time and decisions will normally be made within 6 weeks of receipt

Funding: Trusts

\section{Wellcome Trust and NIH Four-year PhD Studentships}

Subjects: Biomedical science.

Purpose: This scheme provides opportunities for the most promising postgraduate students to undertake international, collaborative fouryear PhD training based in both a UK/Republic of Ireland (Rol) academic institution and the intramural campus of the National Institutes of Health at Bethesda (Maryland, USA).

Eligibility: You should be a UK/European Economic Area (EEA) national with (or be in your final year and expected to obtain) a first- or upper-second-class honours degree or an equivalent EEA graduate qualification. You must have: (1) a suitable doctoral supervisor at an eligible academic host institution in the UK or Republic of Ireland. The host institution must be able to confer doctoral degrees; (2) a suitable supervisor at a NIH institute. The NIH supervisor should hold a tenured or tenured-track position for the proposed period of the award and should be willing to provide funding for the student whilst at the NIH.

Level of Study: Doctorate, Research

Type: Studentship

Value: The studentship is awarded for 4 years with support provided by the Wellcome Trust (in the UK/Republic of Ireland) and the NIH (in the USA). Our funding will provide support for the student's stipend, $\mathrm{PhD}$ fees, college fees (if required) and a contribution towards research costs

Length of Study: 4 year

Frequency: Annual

No. of awards offered: 5

Application Procedure: The application form should be completed and submitted by the closing date. An electronic copy (as a Word document) should be emailed to wtnih@wellcome.ac.uk. One signed hard copy should be addressed to the 'Wellcome Trust-NIH PhD studentships' at the Trust's postal address, see website.

Closing Date: November 2nd (Deadline for applications); January

25-26th (Shortlisted candidate interviews)

Funding: Trusts

For further information contact:

Wellcome Trust-NIH PhD studentships, Wellcome Trust, Gibbs Building, 215 Euston Road, London, NW1 2BE, United Kingdom Email: wtnih@wellcome.ac.uk

\section{Wellcome Trust Four-year PhD Programmes}

Subjects: Biomedical science.

Purpose: To support new, innovative PhD studentship programmes training biomedical scientists.

Eligibility: The programme should be based in an eligible institution in the UK or Republic of Ireland. The principal applicant should be the proposed director of the Programme who should be a recognized international leader in their field with a strong track record in 
postgraduate research training. These new programmes are intended for the support of basic scientists rather than clinicians.

Level of Study: Postgraduate, Research

Type: Grant

Value: 4-years' stipend, University fees at home student rates, contribution towards laboratory expenses in the first year, research expenses for 2-4 years, a contribution towards travel, a contribution towards transferable skills training

Length of Study: 4 years

Frequency: Annual

No. of awards offered: 5

Application Procedure: An electronic copy of the preliminary application (Word 96kB) should be sent to 4yrphd@wellcome.ac.uk.

Closing Date: Varies; refer to website www.wellcome.ac.uk/Funding/ Biomedical-science/Funding-schemes/Strategic-awards-andinitiatives/wtx058687.htm

Funding: Trusts

\section{Wellcome Trust Grants}

Subjects: Biomedical sciences, from the basic sciences related to medicine to the clinical aspects of medicine and veterinary medicine. The Trust also operates a portfolio of schemes to support research in the history of medicine, biomedical ethics and the public engagement of science.

Purpose: To foster and promote research with the aim of improving human and animal health. The Trust aims to: (a) support research to increase understanding of health and disease, and its societal context; (b) support the development and use of knowledge to create health benefit; (c) engage with society to foster an informed climate within which biomedical research can flourish; (d) foster a research community and individual researchers who can contribute to the advancement and use of knowledge; (e) promote the best conditions for research and the use of knowledge.

Eligibility: Eligible institutions in the UK and Republic of Ireland are normally universities, medical schools, or NHS Trusts. Institutions outside the UK and Republic of Ireland must confirm their status with the Wellcome Trust for research grants. Principal applicants are established researchers who are applying from an eligible institution and are able to sign up to the Trust's grant conditions, and normally hold an academic or research post (or equivalent) and have at least 5 yeas' postdoctoral or equivalent research experience. Check website for further details.

Level of Study: Doctorate, Postdoctorate, Postgraduate, Professional development, Research

Type: Research grant or fellowship

Value: Varies

Length of Study: Varies

Frequency: Applications are considered throughout the year

No. of awards offered: Varies

Application Procedure: Applications can be submitted via online application system.

Closing Date: Please visit the website for scheme deadlines

Contributor: Endowment

No. of awards given last year: 951

No. of applicants last year: 2,736

Additional Information: The Wellcome Trust is one of the most richly endowed of all charitable institutions that fund general medical research in the United Kingdom. The Governors review their policy annually in response to proposals from their advisory committees and professional staff.

\section{Wellcome Trust-POST Fellowships in Medical History and Humanities}

Subjects: Medical history and humanities

Purpose: This scheme enables a PhD student or junior fellow funded through the Wellcome Trust Medical History and Humanities (MHH) programme to undertake a 3-month fellowship at the Parliamentary Office of Science and Technology (POST).

Eligibility: Applicants should be in the second or third year of their $\mathrm{PhD}$ or in the first year of a fellowship funded by the MHH Programme. POST is a strictly non-partisan organization. Wellcome Trust-POST Fellows will be required to abstain from any lobbying or party political activity, and generally uphold the principles of parliamentary service, including a commitment to confidentiality, during their time with the Office. All provisionally selected candidates must sign a declaration to this effect. They must also receive security clearance from the parliamentary security authorities as a condition of finally taking up the fellowship.

Level of Study: Postdoctorate, Research

Type: Fellowship

Value: The successful applicant will receive a fully funded 3-month extension to their PhD or fellowship award. While placements typically last 3-months, they may be extended under exceptional circumstances. If the successful applicant is not within reasonable daily travelling distance to POST in London, the Wellcome Trust will consider paying travel and accommodation costs up to a maximum of $£ 2,000$

\section{Frequency: Annual}

Application Procedure: An application should include the application form, your curriculum vitae, a letter of support from your sponsor/ supervisor and a summary of a proposed topic for a POST publication. The summary should be no longer than 1,000 words and should demonstrate: why you think this subject would be of particular parliamentary interest; how the training you have received and your research to date will enable you to carry out this work; your ability to write in a style suitable for a parliamentary (rather than an academic) audience.

Closing Date: November 23rd

Funding: Trusts

Additional Information: Check website for more details.

For further information contact:

Tel: 02076115757

Email: MHgrants@wellcome.ac.uk

\section{Wellcome-Beit Prize Fellowships}

Subjects: Biomedical science.

Purpose: The Wellcome-Beit Prize Fellowships are intended to provide additional recognition for four outstanding biomedical researchers who have been awarded other Wellcome Trust fellowship funding. The awards were inaugurated in 2009 and replaced the Beit Memorial Fellowships for Medical Research

Eligibility: Wellcome-Beit Prize Fellowships are considered during the interview process for Wellcome Trust Research Career Development Fellowships and Intermediate Clinical Fellowships. No separate application is required.

Level of Study: Research

Type: Fellowship

Value: $£ 25,000$ is awarded to each of four selected Research Caree Development Fellows or Intermediate Clinical Fellows in addition to the salary and research expenses already to be funded by the Wellcome Trust. The $£ 25,000$ prize money can be used flexibly in support of the fellows' ongoing research

Frequency: Annual

No. of awards offered: 4

Application Procedure: Submission of application is not required. Funding: Trusts

\section{Wellcome-Wolfson Capital Awards in Biomedical Science}

Subjects: Biomedical science.

Purpose: The Wellcome Trust and the Wolfson Foundation are pleased to announce a call for proposals for science-based capita projects that fall within the Trust's biomedical science remit. This scheme provides capital funding for large-scale projects (above $£ 1,000,000$ ), in partnership with the host institution.

Eligibility: Applicants should be researchers, normally based in the UK or Republic of Ireland, who fulfil our normal eligibility criteria for biomedical research grants.

Level of Study: Research

Type: Grant

Value: Awards over $£ 1,000,000$ will be made

Frequency: Annual

Application Procedure: Prospective applicants are encouraged to contact us in the first instance to explore whether their proposal meets our criteria. This should be done well in advance of the deadline for preliminary applications. Preliminary applications should include: (1) An outline project plan. (2) Its key aims and objectives. (3) How it fits with our strategy and the institutional strategy. (4) The research groups that would benefit (including curriculum vitaes of research 
team leaders and the source(s) of their research funding). (5) Details of funding requested from the funding organizations. (6) A summary of other funding committed or sought. (7) A supporting statement from the vice-chancellor (or equivalent) on behalf of the host institution.

(8) Evidence that the host institution has had preliminary discussions with local planning authorities where appropriate. If successful, a full application will be invited. These should include a full business plan. Closing Date: See website

Funding: Trusts

\section{WENNER-GREN FOUNDATION FOR ANTHROPOLOGICAL RESEARCH}

The Fellowships Office, 470 Park Avenue South, 8th Floor, New York, NY, 10016, United States of America Tel: (1) 2126835000

Fax: (1) 2126839151

Email: inquiries@wennergren.org

Website: www.wennergren.org

Contact: Victoria Malkin, Anthropologist

The Wenner-Gren Foundation for Anthropological Research supports research, conferences, training, archiving and collaboration in all branches of anthropology, including cultural and social anthropology, ethnology, biological and physical anthropology, archaeology and anthropological linguistics, and in closely related disciplines concerned with human origins, development and variation.

\section{Hunt Postdoctoral Fellowships}

Subjects: Anthropology.

Purpose: To support the writing-up of already completed research

Eligibility: Applicants must have a PhD or equivalent at the time of application and must have received a $\mathrm{PhD}$ or equivalent within 10 years of the application deadline. Qualified scholars are eligible without regard to nationality, institutional, or departmental affiliation although preference is given to applicants who are untenured or do not yet have a permanent academic position.

Level of Study: Postdoctorate

Type: Fellowship

Value: Up to US $\$ 40,000$

Frequency: Annual, Twice a year

No. of awards offered: Up to 8

Application Procedure: Applications can be downloaded from the website and must be submitted online.

Closing Date: May 1st

No. of awards given last year: 9

No. of applicants last year: 89

Additional Information: Qualified scholars are eligible without regard to nationality or institutional affiliation.

\section{Wenner-Gren Foundation Dissertation Fieldwork Grants} Subjects: Anthropology.

Purpose: To support basic research in anthropology and to ensure that the discipline continues to be a source of vibrant and significant work that furthers our understanding of humanity's cultural and biological origins, development, and variation.

Eligibility: Students must be enrolled in a doctoral program (or equivalent, if applying from outside the US) at the time of application. Students of all nationalities are eligible to apply. Funding is to support research experiences only not tuition or writing of dissertation. Open to all individuals in a doctoral programme regardless of nationality or country of institution.

Level of Study: Doctorate

Type: Grant

Value: Dissertation Fieldwork Grants provide a maximum of US\$20,000 and the Osmundsen Initiative supplement provides up to an additional $\$ 5,000$ for a maximum grant of US $\$ 25,000$ Frequency: Annual, Twice a year

Application Procedure: Applicants must complete a formal application on an up-to-date form that should be downloaded from the website and should be submitted online at www.wennergren.org Closing Date: May 1st and November 1st

No. of awards given last year: 109

No. of applicants last year: 662

\section{Wenner-Gren Foundation Post-PhD Grants}

Subjects: Cultural anthropology/physical anthropology/biological anthropology/linguistic anthropology plus archaeology.

Purpose: To support basic research in anthropology and to ensure that the discipline continues to be a source of vibrant and significant work that furthers our understanding of humanity's cultural and biological origins, development, and variation.

Eligibility: Open to individuals holding a PhD or equivalent degree to support individual research projects. Applicants can apply regardless of institutional affiliation, country of residence, or nationality.

Level of Study: Postdoctorate

Type: Grant

Value: Up to US $\$ 20,000$

Frequency: Annual, Biannual

Application Procedure: Applicants must download an up-to-date form from the website.

Closing Date: May 1st and November 1st

No. of awards given last year: 42

No. of applicants last year: 220

\section{WESLEYAN UNIVERSITY}

\author{
45 Wyllys Avenue, Middletown, Middlesex County, CT 06459, \\ United States of America \\ Tel: (1) 8606852000 \\ Fax: (1) 8606852171 \\ Email: bkeating@wesleyan.edu \\ Website: www.wesleyan.edu \\ Contact: Ms Brenda Keating, Administrative Assistant
}

Wesleyan University offers instruction in 41 departments and programmes and 50 major fields of study and awards the Bachelor of Arts and graduate degrees. Master's degrees are awarded in 11 fields of study and doctoral degrees in 6 . Students may choose from about 960 courses each year and may be asked to devise, with the faculty, some 1,500 individual tutorials and lessons.

\section{Andrew W Mellon Postdoctoral Fellowship}

Subjects: Humanities and humanistic social sciences.

Purpose: To provide scholars with free time to further their own work in a cross-disciplinary setting, and to associate them with a distinguished faculty.

Eligibility: Open to persons who have received their $\mathrm{PhD}$ within the last 4 years. Scholars who have received their PhD degree after June 2004 in any field of inquiry in the humanities or humanistic social sciences, broadly conceived, are invited to apply.

Level of Study: Postdoctorate

Type: Fellowship

Value: $\cup \$ 50,000$

Frequency: Annual

Country of Study: Any country

No. of awards offered: 1

Application Procedure: Applicants must request a brochure detailing the application process. There is no formal application form.

Applicants should refer to the Center for the Humanities website for instructions on how to apply.

Closing Date: January 4th

Funding: Private

No. of awards given last year: 2

No. of applicants last year: 285

Additional Information: The Fellow must reside in Middletown during the tenure of the fellowship, give one public lecture and teach one course for 20 students.

\section{WILFRID LAURIER UNIVERSITY}

75 University Avenue West, Waterloo, ON, N2L 3C5, Canada Tel: (1) 5198841970

Fax: (1) 5198869351

Email: webmaster@wlu.ca

Website: www.wlu.ca

Contact: Mr Al Hecht, International Relations

Wilfrid Laurier University is well known for offering an extremely high quality academic experience as well as for cultivating a closely-knit 
undergraduate and graduate student population. Wilfrid Laurier University is committed to continuing to provide the educational experiences and environment that foster such development and nurture what can best be described as the 'Laurier spirit'.

\section{Hans Viessmann International Scholarship}

Subjects: All subjects.

Purpose: To assist students wanting to study in Germany.

Level of Study: Postgraduate

Type: Scholarship

Value: $\$ 900$

Length of Study: 1 year

Frequency: Annual

Country of Study: Germany

Application Procedure: Contact University.

Closing Date: July 5th

\section{President Marsden Scholarship}

Subjects: All subjects.

Purpose: To reward a strong student who best exemplifies the mission of Laurier.

Eligibility: Applicant should be a full-time undergraduate or graduate students. Applicants must be Canadian citizens, Permanent Residents (landed immigrants) or Protected Persons.

Level of Study: Postgraduate

Type: Scholarship

Value: Up to Canadian $\$ 1,400$

Length of Study: 1 year

Frequency: Annual

Study Establishment: Laurier University

Country of Study: Canada

No. of awards offered: 1

Application Procedure: Apply online.

Closing Date: October 15th

\section{Ross and Doris Dixon Special Needs Awards}

Subjects: All subjects.

Purpose: To create a positive environment for students with special needs.

Eligibility: No restrictions.

Level of Study: Postgraduate

Type: Scholarship

Value: Varies

Length of Study: 1 year

Frequency: Annual

Study Establishment: Laurier University

Country of Study: Canada

No. of awards offered: 20

Application Procedure: Apply online.

Closing Date: September 30th

Funding: Trusts

Contributor: Ross and Doris Dixon

\section{Viessmann/Marburg Travel Scholarship}

Subjects: All subjects.

Purpose: To assist students wanting to study in Germany.

Level of Study: Postgraduate

Type: Scholarship

Value: $€ 767$

Length of Study: 1 year

Frequency: Annual

Study Establishment: An approved place of study in Marburg

Country of Study: Germany

Application Procedure: Contact University.

Closing Date: July 2nd

\section{Wilfrid Laurier University Postdoctoral Fellowship}

Subjects: All subjects.

Purpose: To provide full-time research opportunities for recent graduates who wish to pursue independent and collaborative research under the supervision of Laurier faculty.

Eligibility: Applicants must be within 5 years of the completion of all $\mathrm{PhD}$ requirements.

Level of Study: Postdoctorate
Type: Fellowship

Length of Study: 1-2 years

Study Establishment: Wilfrid Laurier University

Country of Study: Canada

Application Procedure: Self-funded applicants must submit a copy of their SSHRC or NSERC PDF application, curriculum vitae and a detailed research plan for each year. Applicants who wish to teach will be interviewed by the chair.

\section{William and Marion Marr Graduate Award}

Subjects: All subjects.

Purpose: To aid graduate students with special needs.

Level of Study: Postgraduate

Type: Scholarship

Value: Up to Canadian $\$ 2,000$

Length of Study: 1 year

Frequency: Annual

Study Establishment: Laurier University

Country of Study: Canada

Application Procedure: Apply online.

Closing Date: October 17th

Funding: Private

Contributor: Dr and Mrs Marr

\section{WLU Graduate Incentive Scholarships}

Subjects: All subjects.

Purpose: To reward graduate students who are successful in major external scholarship competitions.

Level of Study: Postgraduate

Type: Scholarship

Value: $\$ 1,000$ to $\$ 9,000$ over a period of $1-3$ years

Length of Study: $1-3$ years

Frequency: Annual

Study Establishment: Laurier University

Country of Study: Canada

No. of awards offered: Varies

Application Procedure: Contact University.

Closing Date: No deadline

\section{WLU Graduate Scholarships}

Subjects: All subjects.

Level of Study: Postgraduate

Type: Scholarship

Value: Canadian $\$ 1,000$

Length of Study: 1 year

Frequency: Annual

Study Establishment: Laurier university

Country of Study: Canada

Application Procedure: Apply online.

Closing Date: October 11th

Additional Information: A scholarship is awarded on academic merit, not financial need.

\section{WLU President's Gold Scholarship}

Subjects: All subjects.

Purpose: To reward significant contribution to the community as a volunteer or to the discipline as a scholar.

Eligibility: Full-time undergraduate students entering year 1. Minimum overall average of 95 per cent in best six Grade $12 \mathrm{U}$ and/or Grade $12 \mathrm{M}$ courses or Ontario Academic Credits (OACs) (or equivalent).

Level of Study: Postgraduate

Type: Scholarship

Value: $\$ 23,000$ ( $\$ 3,0001$ st year; renewable based on academic performance for up to $4^{*}$ years at $\$ 5,000$ per year) * 4 th year of renewal eligibility for approved 5 -year undergraduate programs only Length of Study: 1 year

Frequency: Annual

Study Establishment: Laurier University

Country of Study: Canada

Application Procedure: Apply online.

Closing Date: Refer website

Funding: Trusts

Contributor: Dr Neale H Taylor 


\section{WLU Student International Travel Scholarship}

Subjects: All subjects.

Purpose: To assist Laurier students with travel costs associated with an academic exchange programme.

Level of Study: Postgraduate

Type: Scholarship

Value: Varies

Length of Study: 1 year

Frequency: Annual

Study Establishment: An approved University or Institute

Application Procedure: Contact University.

Closing Date: July 2nd

\section{WILLIAM HONYMAN GILLESPIE SCHOLARSHIP TRUST}

Messrs Tods Murray LLP, Edinburgh Quay, 133 Fountain Bridge, Edinburgh, EH3 9AG, Scotland

Tel: (44) 1316562000

Fax: (44) 1316562020

Email: maildesk@todsmurray.com

Website: www.todsmurray.com

Contact: Trustees

\section{William Honyman Gillespie Scholarships}

Subjects: Theology.

Purpose: To allow the recipient to engage in a full-time approved scheme of theological studies or research.

Eligibility: Open to graduates of a theological college of one of the Scottish universities.

Level of Study: Postgraduate

Type: Scholarship

Value: UK£1,000 per year

Length of Study: 2 years

Frequency: Annual

Study Establishment: An approved university or similar institution Country of Study: Any country

No. of awards offered: Varies, usually 1-2

Application Procedure: Applicants must submit applications through the principal of the theological college of which the applicant is a graduate. Application guidelines are available from the Trust or the candidate's university department.

Closing Date: May 15th

Funding: Private

No. of awards given last year: 2

No. of applicants last year: 2

\section{WILLIAM J. CUNLIFFE SCIENTIFIC AWARDS}

Department of Dermatology, Charité Universitämedizin Berlin, Campus Benjamin Franklin, Fabeckstrasse 60-62,

Berlin, 14195, Germany

Tel: (49) 3084456911

Fax: (49) 3084456908

Email: info@cunliffe-awards.de

Website: www.cunliffe-awards.de

Contact: Professor Dr Christos C. Zouboulis, Chairman of the Executive Committee

The William J. Cunliffe Scientific Awards aim to recognize and encourage innovative and outstanding research in the areas of endocrine dermatology and skin pharmacology, conferring great benefit upon understanding the function of the pilosebaceous unit as well as the pathophysiology and treatment of its disease.

\section{William J. Cunliffe Scientific Awards}

Subjects: The significance of skin, and especially of the pilosebaceous unit, as hormone target and endocrine organ, the development of new molecules to target skin diseases and the understanding of the molecular action of therapeutic compounds.

Purpose: The William J. Cunliffe Scientific Awards aim to recognize and encourage innovative and outstanding research in the areas of endocrine dermatology and skin pharmacology.
Eligibility: Open to persons for any nationality. Living individuals or public or private institutions of any nation, are eligible for nomination. Level of Study: Professional development

Type: Lectureship/Prize

Length of Study: Nominees will be considered for the year of their nomination

Frequency: Dependent on funds available

Country of Study: Worldwide

No. of awards offered: 1 per year (major)

Application Procedure: Applicants must complete an application form. Guidelines can be found on the website www.cunliffe-awards. org. Applicants should be nominated.

Closing Date: May 31st

Funding: Corporation

\section{WILSON ORNITHOLOGICAL SOCIETY}

\author{
Biology Department, Albion College, Albion, MI, 49224, \\ United States of America \\ Tel: (1) 2543999636 \\ Fax: (1) 2547763767 \\ Email: DKennedy@albion.edu \\ Website: www.wilsonsociety.org \\ Contact: Dr Dale Kennedy, President
}

Founded in 1888 and named after Alexander Wilson, the father of American ornithology, the Wilson Ornithological Society publishes a scientific journal, the Wilson Journal of Ornithology, holds annual meetings, provides research awards and maintains an outstanding research library.

\section{George A Hall/Harold F Mayfield Award}

Subjects: Any aspect of ornithology.

Purpose: To encourage and stimulate research projects on birds, by amateurs and students.

Eligibility: Open to independent researchers without access to funds and facilities available at colleges, universities or governmental agencies. The award is restricted to non-professionals.

Level of Study: Unrestricted

Type: Award

Value: US $\$ 1,000$

Frequency: Annual

Country of Study: Any country

No. of awards offered: 1

Application Procedure: An application form must be completed and submitted with three letters of recommendation and a research

proposal. Forms are available from the website.

Closing Date: February 1st

Funding: Private

\section{Louis Agassiz Fuertes Award}

Subjects: Any aspect of ornithology.

Eligibility: Open to all ornithologists, although graduate students and young professionals are preferred. Any avian researcher is eligible.

Level of Study: Unrestricted

Type: Award

Value: US $\$ 2,500$

Frequency: Annual

No. of awards offered: Up to 2

Application Procedure: Application forms are available from the website.

Closing Date: February 1st

No. of awards given last year: 37

\section{WINSTON CHURCHILL FOUNDATION OF THE USA}

600 Madison Avenue, Suite 1601, New York, NY 10022-1737, United States of America Tel: (1) 2127523200

Fax: (1) 2122468330

Email: info@churchillscholarship.org

Website: www.churchillscholarship.org

Contact: Mr Michael Morse, Executive Director 
The Winston Churchill Foundation of the United States was established in 1959 as an expression of American admiration for one of the great leaders of the free world. The foundation enables outstanding American students to attend graduate school at the University of Cambridge.

\section{Churchill Scholarship}

Subjects: Engineering, mathematics, and sciences.

Purpose: To encourage the development of American scientific and technological talent and foster Anglo-American ties.

Eligibility: Open to citizens of the United States of America only Applicants must be enrolled in one of 108 institutions participating in the programme, may not have enrolled in a PhD program and must be within 12 months of graduating college.

Level of Study: Postgraduate

Type: Scholarship

Value: Approx. US $\$ 45,000-60,000$

Length of Study: The Scholarship is tenable from 9 to 12 months, in accordance with the academic program

Frequency: Annual

Study Establishment: Churchill College, the University of Cambridge Country of Study: United Kingdom

No. of awards offered: 14

Application Procedure: Applicants must apply through their sponsoring institution.

Closing Date: November 8th

Funding: Foundation

No. of awards given last year: 14

No. of applicants last year: 100

\section{WINSTON CHURCHILL MEMORIAL TRUST (UK)}

\author{
South Door, Church House, 29 Great Smith Street, \\ London, SW1P 3BL, England \\ Tel: (44) 02077991660 \\ Email: office@wcmt.org.uk \\ Website: www.wcmt.org.uk \\ Contact: Ms Tristan Lawrence, Administrator
}

The WCMT funds British citizens to investigate inspiring practice in other countries, and return with innovative ideas for the benefit of people across the UK. Each year around 150 fellowships are awarded in a range of categories including education, science \& technology, medicine and the environment.

\section{Winston Churchill Memorial Trust (UK) Travelling Fellowships}

Subjects: Approximately 10 wide-ranging categories that vary annually.

Purpose: To enable British citizens from all backgrounds to gain innovative ideas through overseas travel, for the benefit of their UK profession or community.

Eligibility: Open to British citizens resident in the UK aged 18 and above. We do not fund gap year activities, courses, volunteering, academic studies, degree placements, internships, medical electives or post-graduate studies.

Level of Study: Unrestricted

Type: Fellowship

Value: Approx. $£ 6,500$ depending on project.

Length of Study: 4-8 weeks

Frequency: Annual

Country of Study: Outside the United Kingdom

No. of awards offered: Up to 150

Application Procedure: Applicants must complete an online application form.

Closing Date: September; date announced in May for travel the following year

Funding: Individuals

Contributor: The public

No. of awards given last year: 150

No. of applicants last year: 1,030

Additional Information: Any country outside of the UK. Award recipients are announced in February. Fellows may travel from April.

\section{THE WOLFSON FOUNDATION}

8 Queen Anne Street, London, W1G 9LD, England Tel: (44) 02073235730

Fax: (44) 02073233241

Website: www.wolfson.org.uk

Contact: The Chief Executive

The aim of the Wolfson Foundation is the advancement of the arts and humanities, science, health and education. Grants are given to back excellence and talent, generally through the funding of capital infrastructure.

\section{Wolfson Foundation Grants}

Subjects: Medicine and healthcare, including the prevention of disease, and the care and treatment of the sick and disabled, research, science, technology and education, and the arts and humanities, including libraries, museums, galleries, theatres, academies and historic buildings.

Eligibility: Open to registered charities and to exempt charities such as universities. Eligible applications from registered charities for contributions to appeals will normally be considered only when at least 50 per cent of that appeal has already been raised. Grants to universities for research and scholarship are normally made under the umbrella of designated competitive programmes in which vice chancellors and principals are invited to participate from time to time. Applications from university researchers are not considered outside these programmes. Grants are not made to private individuals. Level of Study: Postgraduate, Research

Type: Grant

Value: The Trustees make several types of grants, which are not necessarily independent of each other. Capital Project Grants may contribute towards the cost of erecting a new building or extension, or of renovating and refurbishing existing buildings. Equipment Grants supply equipment for specific purposes and/or furnishing and fittings. Recurrent costs are not normally provided

Frequency: Twice a year

Country of Study: United Kingdom or Israel or The Commonwealth countries

No. of awards offered: Varies

Application Procedure: Applicants must submit in writing a brief outline of the project with one copy of the organization's most recent audited accounts for the past 2 years before embarking on a detailed proposal. Please see website at www.wolfson.org.uk for information before writing.

Closing Date: March 1st or September 1st

Funding: Private

No. of awards given last year: 330

No. of applicants last year: 1,000

\section{THE WOLFSONIAN-FLORIDA INTERNATIONAL UNIVERSITY}

\author{
1001 Washington Avenue, Miami Beach, FL, 33139, \\ United States of America \\ Tel: (1) 3055311001 \\ Fax: (1) 3055312133 \\ Email: research@thewolf.fiu.edu \\ Website: www.wolfsonian.org \\ Contact: Mr Jonathan Mogul, Fellowship Co-ordinator
}

The Wolfsonian-Florida International University is a museum and research centre that promotes the examination of modern material culture. Through exhibitions, publications, scholarships, educational programmes and public presentations, the Wolfsonian strives to enhance the understanding of objects as agents and reflections of social, cultural, political and technological change. The collection includes works on paper, furniture, paintings, sculpture, glass, textiles, ceramics, books and many other kinds of objects.

\section{Wolfsonian-FIU Fellowship}

Subjects: Modern material and visual culture.

Purpose: To conduct research on the Wolfsonian's collection of objects and library materials from the period 1885 to 1945 , including decorative arts, works on paper, books and ephemera. 
Eligibility: The programme is open to holder of Master's or doctoral degrees, $\mathrm{PhD}$ candidates, and to other who have a record of significant professional achievement in relevant fields.

Level of Study: Doctorate, Postdoctorate, Professional development Type: Fellowship

Value: Fellowships include a stipend, accommodations, and roundtrip travel

Length of Study: $3-5$ weeks

Frequency: Annual

Study Establishment: The Wolfsonian-Florida International University

Country of Study: United States of America

No. of awards offered: Varies, approx. 5

Application Procedure: Applicants must complete an application form and submit this with three letters of recommendation. Contact the Fellowship Co-ordinator for details and application materials. Applicants may also download programme information and an application form from the website www.wolfsonian.fiu.edu/education/research/.

Closing Date: December 31st

No. of awards given last year: 5

No. of applicants last year: 26

For further information contact:

Tel: 3055352613

Email: research@thewolf.fiu.edu

\section{WOMEN BAND DIRECTORS INTERNATIONAL (WBDI)}

\author{
7424 Whistlestop Drive, Austin, TX, 78749, \\ United States of America \\ Tel: (1) 5124963591 \\ Fax: (1) 5128413811 \\ Email: dgorzycki@austin.rr.com \\ Website: www.womenbanddirectors.org \\ Contact: Diane Gorzycki, Scholarships Chair
}

Women Band Directors International (WBDI) is an organization in which every woman band director is represented at the international level, regardless of the length of her experience or the level at which she works. It is the only international organization for women band directors.

\section{WBDI Scholarship Awards}

Subjects: Music education.

Purpose: To support young college women presently preparing to be band directors.

Eligibility: Any female student enrolled in college and majoring in music education with the purpose of becoming a band director.

Level of Study: Unrestricted

Type: Award

Value: US $\$ 1,500$

Frequency: Annual

Country of Study: United States of America

No. of awards offered: 5

Application Procedure: Download the application from our websiteessay, 2 letters of recommendations transcript, statement of philosophy, completed application.

Closing Date: December 1st

Funding: Private

No. of awards given last year: 4

No. of applicants last year: 50 per year

\section{WOMEN OF THE EVANGELICAL LUTHERAN CHURCH IN AMERICA (ELCA)}

8765 W. Higgins Road, Chicago, IL, 60631, United States of America

Tel: (1) 8006383522

Fax: (1) 7733801465

Email: info@elca.org

Website: www.womenoftheelca.org
The mission of ELCA is to mobilize women to act boldly on their faiths. As an organization with an anti-racist identity, it offers opportunities for growth by cross-cultural ministry and leadership development.

\section{Amelia Kemp Scholarship}

Subjects: All subjects.

Purpose: To provide assistance to women studying for a career other than the ordained ministry.

Eligibility: Open to female citizens of the US who are members of the ELCA. Be at least 21 years old. Have experienced an interruption in education of two or more years since completion of high school.

Level of Study: Professional development

Type: Scholarship

Value: US\$600-1,000

Length of Study: 1 year

Frequency: Annual

Country of Study: United States of America

No. of awards offered: 1

Application Procedure: A completed application form must be submitted.

Closing Date: February 15th

Contributor: Lutheran Church in America

\author{
Arne Administrative Leadership Scholarship \\ Subjects: Church administration. \\ Purpose: To provide assistance to ELCA women interested in \\ reaching the top of their field as an administrator. \\ Eligibility: Applicant must be a female U.S. citizen who holds a \\ membership in the Evangelical Lutheran Church of America, and has \\ completed a BA or BS degree or its equivalent. \\ Level of Study: Professional development \\ Type: Scholarship \\ Value: Upto US $\$ 2,000$ \\ Frequency: Annual \\ Application Procedure: See the website. \\ Closing Date: February 15th
}

\section{Belmer/Flora Prince Scholarship}

Subjects: Theology.

Purpose: To assist ELCA women as they prepare for ELCA service abroad.

Eligibility: Applicant must be a woman who is a member of the Evangelical Lutheran Church in America and is studying for service abroad. Be at least 21 years old. Have experienced an interruption in education of 2 or more years since completion of high school.

Level of Study: Professional development

Type: Scholarship

Value: US $\$ 800-1,000$

Frequency: Annual

Country of Study: United States of America

No. of awards offered: 2

Application Procedure: Application forms are available on the website.

Closing Date: February 15th

Contributor: Lutheran Church in America

\author{
Herbert W. and Corinne Chilstrom Scholarship for \\ Women Preparing for Ordained Ministry \\ Subjects: Theology. \\ Purpose: To provide assistance to ELCA women during their final \\ year at an ELCA seminary. \\ Eligibility: Open to women candidates of the US who are members of \\ the ELCA. \\ Level of Study: Professional development \\ Type: Scholarship \\ Value: US\$600-1,000 \\ Frequency: Annual \\ Application Procedure: Application form available on the website. \\ Closing Date: February 15th
}




\section{WOMEN'S RESEARCH AND EDUCATION INSTITUTE (WREI)}

714 G Street S.E., Suite 200, Washington, DC, WA, 20003, United States of America

Tel: (1) 2022802720

Fax: (1) 2022934507

Email: WREI@WREI.org

Website: www.wrei.org

Contact: Fellowship Programme

Founded in 1977, Women's Research and Education Institute (WREI) is an independent, non-profit, non-partisan organization governed by a board of directors that includes leading Americans from many fields who are committed to equality for women. Its mission is to inform and help shape the public policy debate on issues affecting women and their roles in the family, workplace and public arena.

\section{Congressional Fellowships on Women and Public Policy}

Purpose: Fellows gains practical policymaking experience and graduate credit as they work in congressional offices.

Eligibility: Students pursuing a graduate degree or those who have recently completed master's, doctorate, or professional degree with a proven commitment to equity for women.

Level of Study: Graduate, MBA, Postgraduate

Type: Fellowship

Value: Stipend of approx. $\$ 1,450$ per month, up to $\$ 500$ for purchase of health insurance, reimbursement up to a maximum of $\$ 1,500$ for the cost of tuition at their home institutions

Length of Study: 8 months

Frequency: Annual

Study Establishment: 1980

Country of Study: United States of America

No. of awards offered: Dependent on funding. For current year, we awarded five fellowships

Application Procedure: Application will be posted on our website www.womenspolicy.org in February.

Closing Date: May 20th

Funding: Corporation, foundation, individuals

Contributor: Amgen, Tulane University, and several individuals

No. of awards given last year: 5

No. of applicants last year: 30

For further information contact:

Women's policy, Inc., 409, 12th St. SW, Ste. 600, Washington, DC 20024

\section{WOMEN'S STUDIO WORKSHOP (WSW)}

722 Binnewater Lane, PO Box 489, Rosendale, NY, 12472, United States of America

Tel: (1) 8456589133

Fax: (1) 8456589031

Email: info@wsworkshop.org

Website: www.wsworkshop.org

Contact: Ms Ann Kalmbach, Executive Director

The Women's Studio Workshop (WSW) is an artist-run workshop with facilities for printmaking, papermaking, photography, book arts and ceramics. WSW supports the creation of new work through studio residency and annual book arts grant programmes and an ongoing subsidized fellowship programme. WSW offers studio-based educational programming in the above disciplines through its annual Summer Arts Institute.

\section{Artists' Book Residencies at WSW}

Subjects: Artists books.

Purpose: To enable artists to produce a limited edition book work at the Women's Studio Workshop.

Level of Study: Unrestricted

Type: Residency grant

Value: The grant includes a stipend of $\$ 350 /$ week, materials up to

$\$ 750$, access to all studios, travel costs up to $\$ 250$ within the

Continental US, and housing.

Length of Study: 6-8 weeks
Frequency: Annual

Study Establishment: WSW

Country of Study: United States of America

No. of awards offered: Varies, usually $3-5$

Application Procedure: Applicants must submit an application including a one-sentence summary followed by a half-page description of the proposed project, the medium or media used to print the book, the number of pages, page size, edition number, a structural dummy, materials budget, a curriculum vitae, 10 slides and a stamped addressed envelope for return of materials. Applications are reviewed by past grant recipients and a WSW staff artist. Applicants should write for an application form or download one from the website plus slide script including title, media, dimension and date.

Closing Date: November 15th

Funding: Government, private

Contributor: Private foundations

No. of awards given last year: 2

No. of applicants last year: 150

\section{Artists Fellowships at WSW}

Subjects: Intaglio, water-based silkscreen, photography, papermaking or ceramics, letterpress, book arts, ceramics.

Purpose: To provide a time for artists to explore new ideas in a dynamic and co-operative community of women artists in a rural environment.

Eligibility: Open to women artists only.

Level of Study: Unrestricted

Type: Fellowship

Value: The award includes on-site housing and unlimited access to the studios. Cost to artists will be US $\$ 200$ per week, plus their own material.

Length of Study: Each fellowship is 3-6 weeks long. Fellowship opportunities are from September to June

Frequency: Annual

Study Establishment: WSW

Country of Study: United States of America

No. of awards offered: $10-20$

Application Procedure: Applicants must complete an application form, available on request or online at the website. One-sentence summary plus half-page description of proposed project, resume,

10 slides plus slide script, self addressed stampe envelope for return of materials.

Closing Date: March 15th or October 15th

Funding: Private, government

Contributor: Private foundations

No. of awards given last year: 25

No. of applicants last year: 100

\section{Studio Residency Grant at WSW}

Subjects: Books, printmaking papermaking, photography and clay. Purpose: To provide artists with time and resources to create a new body of work or to edition a new bookwork.

Eligibility: Open to all national and international applicants. Emerging artists are encouraged to apply.

Level of Study: Unrestricted

Type: Grant

Value: The grant includes a stipend of $\$ 350$ per week, up to $\$ 500$

toward materials used during the residency, travel costs up to $\$ 250$ within the Continental US, housing, and unlimited studio use.

Length of Study: 6-8 weeks

Frequency: Annual

Study Establishment: WSW

Country of Study: United States of America

No. of awards offered: 2

Application Procedure: Applicants must submit an application form a one-semester summary followed by a half-page project description on a separate sheet of paper, a curriculum vitae, ten slides of recent work, a slide script including title, medium, size and date and a stamped addressed envelope, for return of materials. Forms are available from the website.

Closing Date: February 1st

Funding: Foundation, government

No. of awards given last year: 2

No. of applicants last year: 80 


\section{WSW Hands-On-Art Visiting Artist Project}

Subjects: Artist's books.

Purpose: To assist an emerging artist in the creation of a new artist's book, while also working with school children in WSW's studio-based Art-In-Education programme.

Eligibility: Open to all artists. Emerging artists are encouraged to apply.

Level of Study: Unrestricted

Type: Grant

Value: A stipend of up to US $\$ 400$ per week for 10 weeks, plus materials of up to US $\$ 750$ and housing plus travel costs

Length of Study: 8 weeks

Frequency: Annual

Study Establishment: WSW

Country of Study: United States of America

No. of awards offered: 2

Application Procedure: Applicants must apply through a two-part application. Artists apply to WSW, WSW juries and then applies to other funding sources. Artists must submit a one-sentence description plus half-page description of their intended artist book project, including details of the medium to be used for printing the book, number of pages, page size, edition size (100 preferred), a structura dummy, materials budget, a curriculum vitae, a one-page description of relevant work experience with young people, ten slides of recent work and a stamped addressed envelope.

Closing Date: November 15th

Funding: Foundation, government

No. of awards given last year: 2

No. of applicants last year: 30

\section{WSW Internships}

Subjects: Book arts, papermaking, printmaking, ceramics and photography plus arts administration.

Purpose: To provide opportunities for young artists to continue development of their work in a supportive environment, while learning studio skills and responsibilities.

Eligibility: Open to emerging and established female artists.

Level of Study: Unrestricted

Type: Internship

Value: A private room in our onsite housing and a stipend of $\$ 250$ /month.

Length of Study: 2-6 months

Frequency: Annual

Study Establishment: WSW

Country of Study: United States of America

No. of awards offered: 5

Application Procedure: Applicants must submit a curriculum vitae, 10 slides with slide list, 3 current letters of reference, a letter of interest that addresses the question of why an internship at WSW would be important and a stamped addressed envelope. Arts administration:

3 work samples, i.e. press releases, design samples, etc.

Closing Date: See website

Funding: Government, private

Contributor: Private foundations

No. of awards given last year: 6

No. of applicants last year: 150

\section{THE WOODROW WILSON NATIONAL FELLOWSHIP FOUNDATION}

\author{
P O Box 5281, Princeton, NJ, 08543-5281, \\ United States of America \\ Tel: (1) 6094527007 \\ Fax: (1) 6094520066 \\ Email: marrero@woodrow.org \\ Website: www.woodrow.org
}

Contact: Ms Frances Micklow, Communications Associate

The Woodrow Wilson National Fellowship Foundation identifies and develops the best minds for the nation's most important challenges. The fellowships are awarded to enrich human resources, work to improve public policy, and assist organizations and institutions in enhancing practice in the US and abroad.

\section{Charlotte W Newcombe Doctoral Dissertation Fellowships}

Subjects: Religion, ethics, values, humanities and social sciences. Purpose: To encourage new and significant study of ethical or religious values in all fields of humanities and social sciences. Eligibility: Open to students enrolled in doctoral programmes in the humanities and social sciences at a university in the US. Students must have completed all predissertation requirements before the application deadline.

Level of Study: Doctorate

Type: Fellowship

Value: US $\$ 25,000$

Length of Study: 1 year, full-time

Frequency: Annual

Study Establishment: Any appropriate graduate school in the US

Country of Study: Any country

No. of awards offered: Minimum 21

Application Procedure: Applicants must visit the organization website at www.woodrow.org/newcombe.

Closing Date: November

Funding: Private

No. of awards given last year: 22

No. of applicants last year: 600

\section{Thomas R. Pickering Graduate Foreign Affairs \\ Fellowship}

Purpose: Prepare participants for a career as a Foreign Service Officer in the US Department of State.

Eligibility: U.S. citizen, minimum 3.2 GPA on 4.0 scale, entering a 2 -year terminal master's degree program related to international affairs.

Level of Study: Graduate

Type: Fellowship

Value: $\$ 40,000$

Length of Study: 2 years

Frequency: Annual

Country of Study: United States of America

No. of awards offered: 20

Application Procedure: Visit www.woodrow.org.

Closing Date: January 21st

Funding: Government

Contributor: U.S. Department of State

No. of awards given last year: 20

\section{Woodrow Wilson Dissertation Fellowship in Women's Studies}

Subjects: Women's studies, the history, education and psychology of women and women's health.

Purpose: To encourage original and significant research about women that crosses disciplinary, regional or cultural boundaries. Eligibility: Open to doctoral candidates at American universities who have completed all the requirements for the degree course, except the dissertation.

Level of Study: Doctorate

Type: Grant

Value: Up to $\$ 5,000$

Length of Study: 1 year

Frequency: Dependent on funds available

Study Establishment: Any appropriate graduate school in US

Country of Study: Any country

Application Procedure: Applicants must visit the organization website for application procedure.

Closing Date: Varies

Funding: Private

No. of awards given last year: 10

No. of applicants last year: 160

\section{Woodrow Wilson MBA Fellowship in Education Leadership}

Subjects: MBA. The Fellowship program will provide specialized preparation in areas such as leadership, finance, human resources, organizational change-all focusing on education.

Purpose: To address the US' twin educational achievement gapsthe one between the nation's lowest performing and its best schools, 
as well as the one between the nation's best schools and their top international competitors. The Fellowship seeks both to prepare leaders who can bring all American schools up to world-class levels of performance and to develop a new gold standard for preparing education leaders.

Eligibility: Fellows commit to serve for 3 years in approved school or district leadership positions within their states.

Level of Study: Postgraduate

Type: Fellowship

Value: Fellows will receive a stipend to cover tuition for the MBA program and other expenses

Length of Study: The program will require 13-15 months of full-time study, depending on the institution-two summers and an academic year

Frequency: Annual

Application Procedure: Fellows must be nominated by a local education leader/colleague before they are eligible to apply.

Closing Date: December

Additional Information: If you have already been nominated, see the respective pages for the WW MBA Fellowship at MSOE (www.msoe. edu/community/academics/business/page/2311/mba-in-educationleadership-overview) and at Ulndy (http://uindy.edu/education/mbaeducation-leadership) for application deadlines.

\section{Woodrow Wilson Teaching Fellowship}

Subjects: Teacher education, STEM (Science, Technology, Engineering, Mathematics) teaching, secondary school teaching. Eligibility: The Woodrow Wilson Teaching Fellowship seeks to attract talented, committed individuals with science, technology, engineering, and mathematics (STEM) backgrounds - including current undergraduates, recent college graduates, midcareer professionals, and retirees - into teaching in high-need secondary schools. A qualified applicant should demonstrate a commitment to the program and its goals; have U.S. citizenship or permanent residency; have attained, or expect to attain by June 30th, a bachelor's degree from an accredited U.S. college or university; have majored in and/or have a strong professional background in an STEM field; have achieved a cumulative undergraduate grade point average (GPA) of 3.0 or better on a 4.0 scale (negotiable for applicants from institutions that do not employ a 4.0 GPA scale). Note: Prior teaching experience does not exclude a candidate from eligibility. All applications are considered in their entirety and selection is based on merit.

Level of Study: Graduate

Type: Fellowship

Value: $\$ 30,000-\$ 32,000$ stipend, with tuition arrangements varying by campus in Georgia, Indiana, and New Jersey. (Once Fellows are certified teachers at the end of the first year, they obtain salaried employment in high-need schools.)

Length of Study: 12-18 months plus 3-year teaching commitment Frequency: Annual

Study Establishment: Fellowship is only available for use at specific schools in Indiana (Ball State University, Indiana University-Purdue University Indianapolis, Purdue University, and the University of Indianapolis); Michigan (Eastern Michigan University, Grand Valley State University, Michigan State University, University of Michigan, Wayne State University, Western Michigan University); and Ohio (John Carroll University, Ohio State University, University of Akron, and University of Cincinnati)

No. of awards offered: 280

Application Procedure: Online application procedure and supporting documents. See www.wwteachingfellowship.org.

Closing Date: First application deadline - October 16th, Second application deadline November 30th and final application deadline January 31 st

Funding: Foundation, government, private

Contributor: Ohio STEM, Lilly Endowment Inc., W K Kellogg

Foundation, Choose Ohio First

No. of awards given last year: 260

No. of applicants last year: 1690

Additional Information: University of Dayton and University of Toledo are also included in study establishment.

For further information contact:

Tel: 6094527007 ext. 141

Email: wwteachingfellowship@woodrow.org

\section{WOODS HOLE OCEANOGRAPHIC INSTITUTION (WHOI)}

\author{
266 Woods Hole Road, Woods Hole, MA, 02543-1050,
} United States of America

Tel: (1) 5085481400

Fax: (1) 5084572188

Email: information@whoi.edu

Website: www.whoi.edu/education

Contact: Janet Fields, Coordinator

The Woods Hole Oceanographic Institution is a private, independent, non-profit corporation dedicated to research and higher education at the frontiers of ocean science. Its primary mission is to develop and effectively communicate a fundamental understanding of the processes and characteristics governing how the oceans function and how they interact with the Earth as a whole.

\section{CICOR Postdoctoral Scholar Fellowship in Coastal Oceanography, Climate or Marine Ecosystems}

Subjects: Coastal ocean and near shore processes, the ocean's participation in climate and climate variability and marine ecosystem processes analysis.

Purpose: To build ties between WHOI investigators and colleagues at NOAA laboratories and to develop co-operative NOAA funded research at academic institutions in the Northeastern United States of America. The fellowship also aims to further the education and training of recent recipients of doctoral degrees in the marine sciences.

Eligibility: Applicants must have received their doctoral degree within the past 4 years, completed if full in biology, physics, microbiology, molecular biology, chemistry, geology, geophysics, oceanography, meteorology, engineering or mathematics. Candidates should have a command of the English language. Candidates holding a WHOI appointment at the post-PhD level the 12 months prior to the scholar application deadline are not eligible.

Level of Study: Postdoctorate

Type: Fellowship

Value: $\$ 45,250$ (Minimum), \$45,250 (Average), \$45,250 (Maximum)

Length of Study: 18 months

Frequency: Annual

Study Establishment: Woods Hole Oceanographic Institution

Country of Study: United States of America

Closing Date: January 15th

Funding: Government

Additional Information: Award holders work in the laboratory under the general supervision of an appropriate member of the staff, but are expected to work independently on research problems of their own choice.

\section{For further information contact:}

Clark laboratory, MS \#31, Woods Hole Oceanographic Institution, 266 Woods Hole Road, Woods Hole, Massachusetts, 02543-1541, United States of America

Contact: Academic Programs Office

\section{NOSAMS Postdoctoral Fellowships in Marine Radiocarbon Studies and in Accelerator Mass Spectrometry \\ Subjects: Radiocarbon research.}

Purpose: To attract outstanding individuals interested in either or both, studies of radiocarbon in oceanic systems and developments in accelerator mass spectrometry and related techniques. Typical projects include diverse studies of the biogeochemical cycling of carbon, the detection and tracing of pollutants in natural systems and paleoceanographic and paleoclimatic investigations of all kinds. Eligibility: Applicants must have received their doctoral degree before taking up their appointment at Woods Hole. They should have related research interests. Applications from physicists, chemists and biologists as well as from oceanographers are specifically invited. Level of Study: Postdoctorate

Type: Fellowship

Value: Stipend of $\$ 58,000$ per year for an 18 month appointment along with health and dental insurance. Also, some support for travel expenses, equipment, supplies and special services available Length of Study: 18 months 


\section{Frequency: Annual}

Study Establishment: Woods Hole Oceanographic Institution

Country of Study: United States of America

Closing Date: January 5th

\section{For further information contact:}

Clark Laboratory, MS \#31, Woods Hole Oceanographic Institution, 266 Woods Hole Road, Woods Hole, Massachusetts, 02543-1541, United States of America

Contact: Academic Programs Office

\section{WHOI Geophysical Fluid Dynamics (GFD) Fellowships}

Subjects: Classical fluid dynamics, physical oceanography, engineering, geophysics, meteorology, astrophysics, planetary atmospheres, geological fluid dynamics, hydromagnetics, physics and applied mathematics.

Purpose: To bring together graduate students and researchers from a variety of fields who share a common interest in the non linear dynamics of rotating, stratified fields.

Eligibility: There are no eligibility restrictions.

Level of Study: Graduate

Type: Fellowships

Value: A stipend of US\$6,284 and travel allowance

Length of Study: 10 weeks

Frequency: Annual

Study Establishment: Woods Hole Oceanographic Institution

Country of Study: United States of America

No. of awards offered: Up to 10

Application Procedure: Application forms may be obtained from the GFD section of the education website or by writing directly to the Fellowship Committee.

Closing Date: February 15th

Funding: Government

Contributor: The United States office of Naval Research and the United States National Science Foundation

\section{WHOI Marine Policy Fellowship Program}

Subjects: Economic, legal and policy issues that arise from use of the world's oceans.

Purpose: To provide support and experience to research fellows interested in marine policy issues, to provide opportunities for interdisciplinary application of social sciences and natural sciences to marine policy problems, and to conduct research and convey information necessary for the development of effective local, national and international ocean policy.

Eligibility: Applicants must have completed a doctoral level degree or possess equivalent professional qualifications through career experience. The center also welcomes experienced professionals who can arrange a leave or sabbatical.

Level of Study: Postdoctorate

Type: Fellowship

Value: Recipients will receive a stipend of $\$ 57,000$ for a period of

1 year and are eligible for group health and dental insurance. In addition, modest research and travel funds will be made available Length of Study: 1 year

Frequency: Annual

Study Establishment: Woods Hole Oceanographic Institution

Country of Study: United States of America

No. of awards offered: Varies

Application Procedure: A completed application form, a statement of proposed research, a current curriculum vitae including educational background and work experience, transcripts of college and university records and at least 3 personal references.

Closing Date: January 5th

For further information contact:

Clarks laboratory, MS \#31, Woods Hole Oceanographic Institution, Woods Hole, Massachusetts, 02543-1541, United States of America Contact: Academic Programs Office

\section{WHOI Postdoctoral Scholarship Program}

Subjects: Applied ocean physics and engineering, biology, marine chemistry and geochemistry, geology and geophysics, physical oceanography.
Purpose: To further education and training of the applicant with primary emphasis placed on the individual's research promise. Eligibility: Open to applicants who have received their doctoral degree within the past 2-3 years, completed in full. Candidate should have a command of the English language. Candidates holding a WHOI appointment at the post-PhD level during the 12 months prior to the Scholar application deadline are not eligible.

Level of Study: Postdoctorate

Type: Scholarship

Value: $\$ 56,500$ per year

Length of Study: 18 months

Study Establishment: Woods Hole Oceanographic Institution

Country of Study: United States of America

No. of awards offered: 5-6 departmental awards, 4 institute awards Closing Date: January 5th

For further information contact:

Clark Laboratory, MS \#31, Woods Hole Oceanographic Institution, Woods Hole, Massachusetts, 02543-1541, United States of America Contact: Academic Programs Office

\section{WORCESTER POLYTECHNIC INSTITUTE} (WPI)

\author{
100 Institute Road, Worcester, MA 01609-2280, \\ United States of America \\ Tel: (1) 5088315000 \\ Fax: (1) 5088315776 \\ Email: gaann@cs.wpi.edu \\ Website: www.wpi.edu \\ Contact: Dr Matthew Ward, GAANN Director
}

Worcester Polytechnic Institute (WPI) was founded in Worcester, MA in 1865 and was one of the nation's earliest technological universities. From the very beginning, it has taken a unique approach to science and technology education. There are over 20 WPI's project centres throughout North America and Central America, Africa, Australia, Asia and Europe.

\section{Graduate Assistance in Areas of National Need (GAANN)} Award

Subjects: Computer science.

Purpose: To make important contributions to the computer science research community.

Eligibility: Open to citizens or permanent residents of the US

pursuing a $\mathrm{PhD}$ in computer science.

Level of Study: Doctorate

Type: Fellowships

Value: US $\$ 30,000$ per year

Length of Study: 3 years

Frequency: Annual

Country of Study: United States of America

No. of awards offered: 5

Application Procedure: Applicants must send a letter of intent, curriculum vitae and a description of any coursework or research completed.

Closing Date: April 1st for consideration for the Fall semester or November 1st for the Spring semester

\section{WORLD BANK INSTITUTE}

\author{
1818 H Street, Washington, NW, DC 20433, \\ United States of America \\ Tel: (1) 2024731000 \\ Fax: (1) 2024776391 \\ Email: pic@worldbank.org \\ Website: www.worldbank.org \\ Contact: Communications Officer
}

One of the largest sources of funding and knowledge for transition and development councils; The World Bank uses its financial resources, staff and extensive experience to help developing countries reduce poverty, increase economic growth and improve their quality of life. 


\section{Social Development Civil Society Fund}

Subjects: Civil engagement.

Purpose: To strengthen the voice and influence of poor and marginalized groups.

Eligibility: Applicable for Civil society organizations based in a developing country and working on issues of development can apply for a grant. Civil society organizations must be in good standing and have a record of achievement.

Level of Study: Postgraduate

Type: Grant

Value: Each grant will range around $\$ 10,000$

Frequency: Annual

Application Procedure: Guidelines and application forms available from the participating World Bank country office.

Closing Date: April 2nd

Contributor: The World Bank

\section{World Bank Grants Facility for Indigenous Peoples}

Subjects: Indigenous culture, intellectual property and human rights. Purpose: To support sustainable and culturally appropriate development projector planed and implemented by and for Indigenous People. Eligibility: Applicant must be an Indigenous Peoples' community or not-for-profit/non-governmental Indigenous Peoples' organization, must be legally registered in the country of grant implementation, the country must be eligible to borrow from the World Bank (IBRD and/or IDA). Applicant should have an established bank account in the name of the applicant organization and should demonstrate internal controls to govern the use of funds. Applicant should not have received a grant from the Grants Facility for Indigenous Peoples in the previous 2 years.

Level of Study: Professional development, Research

Type: Grant

Value: Proposed project budget requests should range between US $\$ 10,000$ and US $\$ 30,000$ and include a minimum contribution of 20 per cent of the total project cost

Frequency: Annual

Application Procedure: A complete application, not more than

10 pages, should be submitted.

Closing Date: November 15th

Contributor: The World Bank

For further information contact:

World Bank Grants Facility for Indigenous Peoples, Social Development Department, Mailstop MC 5-52b, World Bank, 1818 H Street,

Washington, NW, DC 20433, United States of America

Fax: (1) 2025221669

Email: indigenouspeoples@worldbank.org

\section{WORLD CANCER RESEARCH FUND INTERNATIONAL}

Second Floor, 22 Bedford Square, London, WC1B 3HH, United Kingdom

Tel: (44) 02073434240

Fax: (44) 02073434220

Email: research@wcrf.org

Website: www.wcrf.org

Contact: Science Programme Manager (Research Funding)

\section{World Cancer Research Fund International Regular Grant Programme}

Subjects: World Cancer Research Fund International accepts grant applications for research on the links between diet, nutrition, body composition, physical activity and cancer as part of its Regular Grant Programme. Grant calls open each year mid-July and the deadline for submissions is on the second week of October.

Purpose: Research the links between diet, nutrition, body composition, physical activity and cancer.

Eligibility: The Regular Grant Programme accepts applications from universities, medical schools, NHS Trusts, research institutes and other academic centres. Research for commercial organizations is not eligible for a grant. The Principal Investigator must hold a senior established research position (not a PhD student) at the host institution.
Type: Pilot Grant

Value: maximum of $£ 250,000$ for up to 4 years, with a limit of $£ 75,000$ for any 1 year

Length of Study: Up to 4 years (IIG); up to 2 years (pilot grant)

Frequency: Annual

Application Procedure: Application is via an online form and additional attachments need to be completed and uploaded. Applicants must read the application guidelines carefully before applying. Closing Date: October 9th

Additional Information: Visit www.wcrf.org for more information. Country of study Anywhere in the world except the Americas (North America, Central America including the Caribbean, and South America). Collaborations with the Americas are allowed, but the Principal Investigator must be based outside the Americas.

\section{WORLD FEDERATION OF INTERNATIONAL MUSIC COMPETITIONS}

104, rue de Carouge, Genève, CH - 1205, Switzerland Tel: (41) 223213620

Fax: (41) 227811418

Email: info@beethoven-comp.at, fmcim@fmcim.org Website: www.beethoven-comp.at

The artistic reputation of musicians is highly dependent upon the quality of their Beethoven interpretations. The International Beethoven Piano Competition in Vienna gives young pianists the possibility to demonstrate their musicianship and artistic maturity

\section{International Beethoven Piano Competition Vienna}

Subjects: Piano.

Purpose: To encourage the artistic development of young pianists.

Eligibility: Open for pianists born between January 1, 1981 and

December 31, 1996.

Level of Study: Unrestricted

Type: Competition

Value: The first prize is $€ 8,000$, a Boesendorfer Model 200 piano and engagements, the second prize is $€ 6,000$, the third prize is $€ 4,500$, and there are three further prizes of $€ 2,000$. All information subject to change

Frequency: Every 4 years

Country of Study: Austria

No. of awards offered: 6

Application Procedure: Apply online through the website www.

beethoven-comp.at.

Closing Date: October 15th

Funding: Government, private

No. of awards given last year: 6 plus special prizes

No. of applicants last year: 207

Additional Information: Please refer to the website for more details.

For further information contact:

Competition office, University of Music and Performing Arts, Antonvon-Webern Platz 1, Vienna, A-1030, Austria

Tel: (43) $171155 / 5113$

Fax: (43) $171155 / 5199$

Email: info@beethoven-comp.at

Website: www.beethoven-comp.at

\section{WORLD WILDLIFE FUND (WWF)}

US Headquarters 1250, NW 24th Street, PO Box 97180, Washington, DC, 20090-7180, United States of America Tel: (1) 2022934800

Email: membership@wwfus.org Website: www.worldwildlife.org

World Wildlife Fund (WWF) is known to everyone by its panda logo and leads international efforts to protect endangered species and their habitats. Now in its 5th decade, WWF works in more than 100 countries around the globe to conserve the diversity of life on earth. 


\section{Russell E. Train Fellowships for Master's or Doctoral Degree}

Subjects: The fellowship is awarded in conservation.

Purpose: Train Fellowships support individuals for pursuing a master's or doctoral degree.

Eligibility: Applicants must be a citizen and legal permanent resident of a participating country and have a minimum of 2 years of work experience in conservation and a clear interest in working in their home country or region. Applicants should be enrolled, admitted, or have applied to an institution of higher education before submitting your application. For detailed information, please visit website.

Type: Fellowship

Value: Applicants may request up to US $\$ 30,000$ per year

Application Procedure: The mode of applying is online.

Closing Date: March 1st

Contributor: WWF

Additional Information: Applicants can apply to attend any university around the world and must return to their home countries to work in conservation for at least 2 years. Applicants from Botswana,

Cambodia, Democratic Republic of Congo (en Françias), Mesoamerican Reef - Belize, Guatemala, Honduras (en Español), Myanmar, Namibia, Zambia are eligible for these Russell E. Train Fellowships. Duration of fellowship will be of 2 years.

\section{WWF Fuller Fellowships}

Subjects: Natural and social sciences.

Purpose: To help scientists to address research questions that will powerfully inform and improve the practice of biodiversity conservation. Eligibility: Open to candidates who have obtained a Doctoral degree. Level of Study: Postdoctorate

Type: Fellowships

Value: Fellows may receive up to $\$ 15,000$ per year for expenses and the host institution may receive an allowance of up to $\$ 2,500$ per year Length of Study: 2 years

Frequency: Annual

No. of awards offered: 2

Application Procedure: Applicants can apply online.

Closing Date: Check website for the next deadline

Additional Information: The fellowship is not applicable to employees of WWF-US or immediate family members of WWF-US employees.

\section{WWF Prince Bernhard Scholarship for Nature \\ Conservation}

Subjects: Any field that is directly relevant to the delivery and promotion of conservation.

Purpose: To provide financial support to individuals who wish to pursue professional training or formal studies that will help them to contribute more effectively to conservation efforts in their country. Eligibility: For individuals working in the field of conservation or associated disciplines directly relevant to the delivery and promotion of conservation. Open to candidates from developing countries, central and eastern Europe and the Middle East.

Level of Study: Postgraduate

Type: Scholarship

Value: Swiss Franc 10,000

Frequency: Annual

Closing Date: January 5th

Contributor: World Wide Fund for Natures international programme based in Gland, Switzerland

\section{THE WORSHIPFUL COMPANY OF FOUNDERS}

\author{
Founders' Hall, Number One, Cloth Fair, London, \\ EC1A 7JQ, England \\ Email: FoundersCompany@aol.com \\ Website: www.foundersco.org.uk \\ Contact: A.J. Gillett
}

\section{Malcolm Ray Travelling Scholarship}

Subjects: Materials engineering.

Purpose: To help candidates advance both personal skills and professional knowledge.
Eligibility: Open to applicants studying materials engineering and who are under the age of 28 , and can put forward an imaginative and testing project outside the UK.

Level of Study: Postgraduate, Professional development

Type: Scholarship

Value: UK£3,000

Frequency: Every 2 years

No. of awards offered: 1

Closing Date: April 20th

Funding: Trusts

Contributor: Malcolm Ray Travelling Scholarship

No. of awards given last year: 2

\section{THE WORSHIPFUL COMPANY OF MUSICIANS}

6th Floor, 2 London Wall Buildings, London, EC2M 5PP, England Tel: (44) 2074968980

Fax: (44) 2075883633

Email: deputyclerk@wcom.org.uk

Website: www.wcom.org.uk

Contact: Ms Margaret Alford, Clerk

The Worshipful Company of Musicians supports young musicians particularly in the wilderness years between graduating and setting out on their musical careers.

\section{Allcard Grants + Busenhart-Morgan-Evans Award Subjects: Music.}

Purpose: To support the advanced training of performers at home or abroad for string, voice or piano accompanists, and wind instruments in exceptional circumstances.

Eligibility: Open to individuals wishing to undertake a relevant training or research programme. The grants are not available for courses leading either to a first degree at a university or to a diploma at a college of music, and only in exceptional circumstances will assistance towards the cost of a 4 th or 5 th year at a college of music be considered. Grants are not available towards the purchase of instruments. Applicants must have studied at a British institution for at least 3 years.

Level of Study: Postgraduate

Type: Grant

Value: Up to UK£6,000

Frequency: Annual

Country of Study: Any country

No. of awards offered: 4

Application Procedure: Applicants must be nominated by principals or heads of music departments at the Royal Academy of Music, the Royal College of Music, the Guildhall School of Music, the Royal Northern College of Music, the Royal Scottish Academy of Music, the Welsh College of Music, the Birmingham Conservatoire, the Trinity

College of Music, City University, Huddersfield University, Goldsmiths or other university departments.

Closing Date: Applications are to be made after January 1st and before April 30th

Funding: Trusts

No. of awards given last year: 4

No. of applicants last year: 30

\section{Carnwath Scholarship}

Subjects: Music.

Purpose: To support young pianists

Eligibility: Open to any person permanently resident in the United Kingdom and 21-25 years of age. The scholarship is intended only for the advanced student who has successfully completed a solo

performance course at a college of music.

Level of Study: Postgraduate

Type: Scholarship

Value: UK£4,150 per year

Length of Study: Up to 2 years

Frequency: Every 2 years

Country of Study: United Kingdom

No. of awards offered: 1

Application Procedure: Applicants must be nominated by principals of the Royal Academy of Music, the Guildhall School of Music, the Royal Northern College of Music, the Royal Scottish Academy of 
Music, Trinity College of Music, London College of Music, the Welsh College of Music, the Birmingham School of Music or the Royal College of Music. No application should be made directly to the Worshipful Company of Musicians.

Closing Date: April 30th

Funding: Trusts

\section{Goldman Award}

Purpose: To support the advanced training of performers at home or abroad for string, voice, piano accompanists and wind instruments in exceptional circumstances.

Eligibility: Open to individuals wishing to undertake a relevant training or research programme. Applications must have studied at a British institution for at least 3 years.

Type: Grant

Value: Up to $£ 2,000$

Frequency: Annual

Application Procedure: By nomination only by principals or heads of music departments at the major music colleges/conservatories or university departments.

Closing Date: April 30th

No. of awards given last year: 1

Additional Information: Please check website for more details.

\section{John Clementi Collard Fellowship}

\section{Subjects: Music.}

Eligibility: Open to professional musicians of standing and experience who show excellence in one or more of the higher branches of musical activity, such as composition, research and performance including conducting.

Level of Study: Postgraduate

Type: Fellowship

Value: UK£5,000 per year

Length of Study: 1 year

Frequency: Dependent on funds available, Approx. every 3 years

Country of Study: United Kingdom

No. of awards offered: 1

Application Procedure: Applicants can be nominated by professors of music at Oxford, Cambridge or London Universities, directors of the Royal College of Music, principals of the Royal Academy of Music, the Guildhall School of Music or the Royal Northern College of Music. Applications can be made directly to the Worshipful Company of Musicians.

Additional Information: Please check website for more details.

\section{Maisie Lewis Young Artists Fund \& Concordia}

\section{Foundation Artists Fund}

Subjects: Musical performance.

Purpose: To assist young artists of outstanding ability who wish to acquire experience on the professional soloist concert platform.
Eligibility: Open to instrumentalists up to 27 years of age and to singers of up to 32 years of age.

Level of Study: Postgraduate

Value: Reimbursement of recitalists' expenses

Frequency: Annual

Country of Study: United Kingdom

No. of awards offered: 6 half recitals per year

Application Procedure: Applicants must complete an application form, available from October 15th.

Closing Date: December 11th

Funding: Trusts

No. of awards given last year: 6

No. of applicants last year: 80

Additional Information: Auditions are held in March.

\section{WRITTLE UNIVERSITY COLLEGE} Lordship Road, Writtle, Chelmsford, CM1 3RR,
United Kingdom

Tel: $(44)+1245424200$

Contact: Writtle University

Writtle University College is one of the largest land-based university colleges in the UK; it is also one of the oldest. Set in the Essex countryside on a 220 hectare estate, Writtle, previously known as Writtle College provides FE and HE programmes.

\section{Postgraduate International Scholarships}

Subjects: Scholarships are awarded to study the subjects offered by the university.

Purpose: Scholarships are available for pursuing postgraduate programme.

Eligibility: The scholarship is only available to new postgraduate Writtle University College students. Applicants whose first language is not English are usually required to provide evidence of proficiency in English at the higher level required by the University.

Level of Study: Postgraduate

Value: For taught MA/MSc courses, the award will be worth $£ 1,000$; for MA conversion students the award will be delivered within the conversion year ONLY, as per the terms and conditions set out below

Length of Study: 2 years

Application Procedure: Applications to be sent via email. For more details, please refer website: http://scholarship-positions.com/writtleuniversity-college-postgraduate-international-scholarships-uk/2017/ 10/23/.

Closing Date: August 31st

Contributor: Writtle University 